University of Michigan Law School University of Michigan Law School Scholarship Repository

2009

\title{
Sentence Reduction as a Remedy for Prosecutorial Misconduct
}

Sonja B. Starr

University of Michigan Law School, sbstarr@umich.edu

Available at: https://repository.law.umich.edu/articles/1189

Follow this and additional works at: https://repository.law.umich.edu/articles

Part of the Constitutional Law Commons, Criminal Law Commons, Legal Ethics and Professional Responsibility Commons, and the Legal Remedies Commons

\section{Recommended Citation}

Starr, Sonja B. "Sentence Reduction as a Remedy for Prosecutorial Misconduct." Geo. L. J. 97, no. 6 (2009): 1509-66.

This Article is brought to you for free and open access by the Faculty Scholarship at University of Michigan Law School Scholarship Repository. It has been accepted for inclusion in Articles by an authorized administrator of University of Michigan Law School Scholarship Repository. For more information, please contact mlaw.repository@umich.edu. 


\title{
Sentence Reduction as a Remedy for Prosecutorial Misconduct
}

\author{
SONJA B. STARR*
}

Current remedies for prosecutorial misconduct, such as reversal of conviction or dismissal of charges, are rarely granted by courts and thus do not deter prosecutors effectively. Further, such all-or-nothing remedial schemes are often problematic from corrective and expressive perspectives, especially when misconduct has not affected the trial verdict. When granted, these remedies produce windfalls to guilty defendants and provoke public resentment, undermining their expressive value in condemning misconduct. To avoid these windfalls, courts refuse to grant any remedy at all, either refusing to recognize violations or deeming them harmless. This often leaves significant non-conviction-related harms unremedied and egregious prosecutorial misconduct uncondemned and undeterred.

This Article proposes adding sentence reduction to current remedial schemes, arguing that this would provide courts with an intermediate remedy that they would be more willing to grant. The Article demonstrates that several prosecutorial incentives combine to make sentence reduction an effective deterrent. Moreover, because sentence reduction could be tailored to the magnitude of the violation, it could resolve the windfall dilemma and serve as an effective corrective and expressive remedy.

\section{TABLE OF CONTENTS}

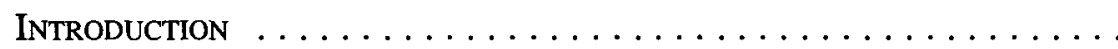

I. The Failure of Current Remedies for Prosecutorial

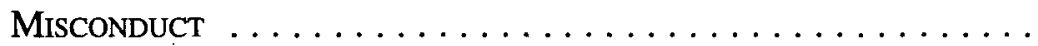

II. Sentence Reduction as an Alternative Remedy . . . . . . . . . 1518

A. THE PROPOSAL . . . . . . . . . . . . . . . . . . 1519

B. SENTENCE REDUCTION AND REMEDIAL DETERRENCE . . . . . . 1520

* Assistant Professor, University of Michigan School of Law. (c) 2009, Sonja Starr. Thanks to Richard Boldt, Eve Brensike Primus, David Gray, Deborah Hellman, Andy Hessick, Carissa Byrne Hessick, Yale Kamisar, Dan Meltzer, J.J. Prescott, Alice Ristroph, Jeannie Suk, David Super, and Sean Williams for comments on drafts and to Jeff Dubner for research assistance and comments. Earlier drafts have been presented at the Junior Criminal Law Scholars Conference, Harvard Law School's Climenko Workshop, the University of Michigan Faculty Legal Theory Workshop, and the University of Maryland Faculty Workshop-thanks to all participants for their insights. 
III. Sentence Reduction as a Deterrent: Prosecutors' INCENTIVES

A. THE GAINS OFFERED BY MISCONDUCT $\ldots \ldots \ldots \ldots \ldots \ldots \ldots, 1522$

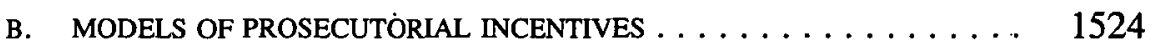

1. Deterring Crime . . . . . . . . . . . . . . 1524

2. Efficient Case Processing . . . . . . . . . . . . 1525

3. Career Advancement . . . . . . . . . . . . 1526

4. Winning $\ldots \ldots \ldots \ldots \ldots \ldots \ldots \ldots \ldots \ldots \ldots \ldots \ldots \ldots \ldots \ldots \ldots$

5. Political Gain . . . . . . . . . . . . . . . 1529

6. Justice . . . . . . . . . . . . . . . . . . . 1529

C. EVIDENCE ABOUt REAL PROSECUTORS' PREFERENCES $\ldots \ldots \ldots 1530$

IV. Sentence Reduction as a Corrective and Expressive Remedy . . 1532

A. CRIMINAL PROCEDURE REMEDIES AS CORRECTIVE JUSTICE ..... 1532

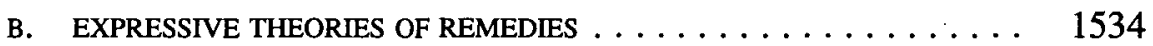

C. THE Windfall PROBLEM $\ldots \ldots \ldots \ldots \ldots \ldots \ldots \ldots \ldots \ldots$

D. SENTENCE REDUCTION AS A TAILORED REMEDY $\ldots \ldots \ldots \ldots \ldots .1539$

E. REMEDIAL SENTENCE REDUCTION AND THE GOALS OF SENTENCING $\ldots \ldots \ldots \ldots \ldots \ldots \ldots \ldots \ldots \ldots \ldots$

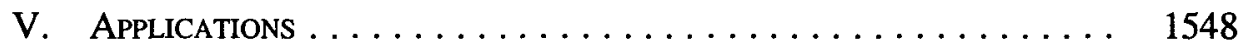

A. SPEedy tRIaL VIOLATIONS $\ldots \ldots \ldots \ldots \ldots \ldots \ldots \ldots \ldots \ldots \ldots$

B. RACE DISCRIMINATION IN JURY AND JURY VENIRE SELECTION . . . 1551

C. HARMLESS ERRORS $\ldots \ldots \ldots \ldots \ldots \ldots \ldots \ldots \ldots \ldots \ldots \ldots \ldots \ldots \ldots$

VI. Practicalities . . . . . . . . . . . . . . . . . . . 1557

A. Legislative APPROAChes $\ldots \ldots \ldots \ldots \ldots \ldots \ldots \ldots \ldots \ldots$

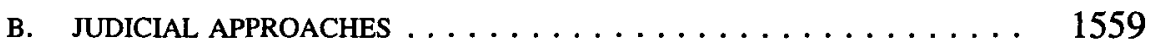

C. IMPLEMENTATION CONCERNS: RESPONSES TO OBJECTIONS $\ldots \ldots \quad 1562$

Conclusion $\ldots \ldots \ldots \ldots \ldots \ldots \ldots \ldots \ldots \ldots \ldots \ldots \ldots \ldots \ldots \ldots \ldots$

INTRODUCTION

Remedies for violations of criminal defendants' procedural rights are often all 
or nothing. Convictions are either reversed or affirmed; charges are either thrown out or let stand; evidence is either excluded or admitted. These remedies pose serious dilemmas for courts. When granted, they often result in windfalls for guilty defendants - and courts, as Judge Guido Calabresi has noted, "are not in the business of letting people out on technicalities." But under the current system, if courts do not want to grant such windfalls, they cannot grant any remedy at all. They must either avoid recognizing a rights violation or deem violations harmless. This problem has been especially acute with respect to prosecutorial misconduct. As many scholars have observed, the existing remedies for prosecutorial misconduct are ineffective, largely because they are rarely invoked. ${ }^{2}$

To address this problem, this Article proposes adding to courts' remedial toolkit an intermediate remedy for prosecutorial misconduct: reduction of the defendant's sentence. I do not propose sentence reduction where misconduct has undermined the reliability of the conviction. In such cases, the defendant should not be sentenced at all. But misconduct often inflicts serious dignitary and emotional harms independent of the effect on the verdict. For instance, a defendant who learns that the prosecution has hidden potentially exculpatory evidence may suffer lifelong distrust and resentment of the government, even if the defendant discovers the evidence in time to avoid any effect on the verdict. Likewise, long delays in trial can cause major stress and inconvenience for defendants. And even when misconduct is truly "harmless" to the particular defendant, sanctions may be necessary to condemn it effectively and to deter its repetition. Sentence reduction could serve these corrective, expressive, and deterrent purposes.

Sentence reduction is an accepted remedy in a number of other jurisdictions for various violations of criminal defendants' rights. It has been approved, for instance, by the European Court of Human Rights, ${ }^{3}$ some European domestic courts, ${ }^{4}$ several Canadian provincial supreme courts, ${ }^{5}$ and the Appeals Chamber for the International Criminal Tribunal for Rwanda. ${ }^{6}$ But it is essentially unknown in U.S. courts. The one time the Supreme Court considered sentence reduction as a remedy for a non-sentencing-related procedural error (a Speedy

1. Guido Calabresi, The Exclusionary Rule, 26 HaRv. J.L. \& PuB. PoL'y 111, 112 (2003).

2. See infra Part I.

3. E.g., Chraidi v. Germany, 47 Eur. Ct. H.R. 2, III 24-25 (2006) (excessive pretrial detention); Scordino v. Italy (No. 1), 45 Eur. Ct. H.R. 7, III 185-86 (2006) (speedy trial); Mathew v. Netherlands, 43 Eur. Ct. H.R. 23, TII 148-49 (2005) (unlawful conditions of detention).

4. E.g., Salah v. Netherlands, 44 Eur. Ct. H.R. 55, TII 30-40, 74 (2006) (discussing Dutch cases); Yetkinsekerci v. United Kingdom, 43 Eur. Ct. H.R. 4, I 8 (2005) (quoting U.K. case).

5. E.g., R. v. MacPherson, [1995] 166 N.B.R.2d 81, gt 15-16 (Can.) (remedying delay before arraignment); R. v. Stannard, [1989] 79 Sask. R. 257, II 12 (Can.) (unlawful search).

6. E.g., Barayagwiza v. Prosecutor, Case No. ICTR 97-19-AR72, Decision on Prosecutor's Request for Review or Reconsideration, TII 74-75 (Mar. 31, 2000) (unlawful delay in indictment and appointment of counsel); see Sonja Starr, Rethinking "Effective Remedies": Remedial Deterrence in International Courts, 83 N.Y.U. L. Rev. 693, 717-18 (2008). 
Trial Clause violation), the Court rejected it, reiterating its cursory conclusion in an earlier speedy trial case that dismissal with prejudice was " "the only possible remedy.", Nor have lower U.S. courts embraced remedial sentence reduction, with one very recent exception: a federal district court case, United States $v$. Dicus, which relied on arguments contained in a draft version of this Article. ${ }^{8}$

U.S. scholarship has likewise almost entirely ignored this possible remedy. However, two pieces on the Fourth Amendment exclusionary rule have proposed sentence reduction as an alternative - one by Judge Calabresi ${ }^{9}$ and one by Harry Caldwell and Carol Chase. ${ }^{10}$ Both would combine sentence reduction with direct sanctions against the police, such as fines. Their theory is that the direct sanctions would deter misconduct while sentence reduction would give defendants an incentive to raise claims. ${ }^{11}$ In a response to Calabresi's piece, Yale Kamisar argues that this combined scheme would not accomplish the deterrent purpose of the exclusionary rule. ${ }^{12}$ First, he observes, as Calabresi concedes, ${ }^{13}$ that sentence reduction itself will not deter police misconduct because the police do not care "one whit" about sentencing. ${ }^{14}$ Second, direct sanctions would not work - the police are politically powerful, and judges have historically been loath to closely supervise and sanction them. ${ }^{15}$ Both arguments are plausible, ${ }^{16}$ and Kamisar may well be right that sentence reduction would

7. Strunk v. United States, 412 U.S. 434, 439-40 (1973) (quoting Barker v. Wingo, 407 U.S. 514, 522 (1972)); see infra section V.A.

8. United States v. Dicus, 579 F. Supp. 2d 1142, 1159-61 (N.D. Iowa 2008); see Sonja B. Starr, Using Sentencing to Clean Up Criminal Procedure: Incorporating Remedial Sentence Reduction Into Federal Sentencing Law, 21 FED. SENT'G. ReP. 29, 29 (2008) (discussing Dicus).

9. Calabresi, supra note 1 , at 116.

10. Harry M. Caldwell \& Carol A. Chase, The Unruly Exclusionary Rule: Heeding Justice Blackmun's Call to Examine the Rule in Light of Changing Judicial Understanding About Its Effects Outside the Courtroom, 78 MARQ. L. Rev. 45, 73-74 (1994).

11. Calabresi, supra note 1, at 116-17; Caldwell \& Chase, supra note 10, at 68-71'.

12. 'Yale Kamisar, In Defense of the Search and Seizure Exclusionary Rule, 26 HaRv. 'J.L. \& PuB. PoL'y 119, 136 (2003).

13. Calabresi, supra note 1 , at 116 .

14. Kamisar, supra note 12, at 136.

15. Id. at $127-29,138$.

16. With regard to his first point, Kamisar cites no studies of police attitudes concerning sentencing, and I have found none. However, Josh Bowers notes that low sentences sometimes help police effectiveness by reducing community resentment, suggesting that police might not prefer higher sentences. See Josh Bowers, Grassroots Plea Bargaining, 91 MarQ. L. Rev. 85, 93-94 (2007). In addition, one recent study found that increased prosecutorial screening of cases did not affect police practices-police were "willing to suffer a refusal to prosecute." Daniel Richman, Institutional Coordination and Sentencing Reform, 84 TEx. L. Rev. 2055, 2059 (2006). If police are indifferent to whether their cases are prosecuted at all, they probably do not care about sentences either-but this would also mean that the exclusionary rule itself would have limited deterrent effect.

In support of his second argument, Kamisar, supra note 12, at 138-39, observes that under a direct sanction system for INS officers who conduct unlawful searches, sanctions were almost never invoked. See INS v. Lopez-Mendoza, 468 U.S. 1032, 1054 (1984) (White, J., dissenting). Kamisar also cites evidence of the political power of police, Kamisar, supra note 12 at 129 (noting failure of "many other 'direct sanctions' proposals"), and scholarship arguing that judges often tolerate police perjury, id. at 130. As I show in Part I, courts virtually never directly sanction prosecutors. It seems plausible that 
not work as an alternative to the exclusionary rule.

But even if sentence reduction does not deter police misconduct, it might well deter prosecutorial misconduct. Unlike police, prosecutors are likely to care about sentence reductions. Although their motivations vary, prosecutors have many reasons to prefer longer sentences: political pressures; ideology, office policy and culture, and career interests. And even a prosecutor who lacks that preference would face embarrassment if a sentence were reduced on the express basis of her wrongdoing. To be sure, prosecutors would presumably rather have a sentence lowered than a conviction thrown out. But a less serious though more likely penalty could provide a bigger deterrent.

Sentence reduction is also an attractive corrective and expressive remedy. It would vindicate the defendant's rights in a nontrivial way, providing a remedy that matters to the defendant. Moreover, it could effectively condemn the misconduct and reaffirm the defendant's rights and dignity, strengthening rule-oflaw social norms and discouraging misconduct in the future. But because the reduction's magnitude could be tailored to the violation, it need not create major windfalls that offend the community's sense of justice and undermine the remedy's expressive and corrective purposes. And because it is not such a windfall, courts will likely be more willing to invoke it than current, nominally stronger remedies-thus serving all remedial purposes better than the current all-or-nothing choices that usually drive courts to pick "nothing."

Part I argues that courts' reluctance to invoke current remedies leaves most prosecutorial misconduct unredressed. Part II outlines my proposal and argues that courts would be much less reluctant to grant sentence reductions. Part III examines prosecutors' incentives and explains why sentence reduction would deter misconduct. Part IV argues that sentence reduction would be an effective corrective and expressive remedy. Part $\mathrm{V}$ explores three contexts in which sentence reduction could apply: speedy trial violations, race discrimination in jury selection, and misconduct that is presently deemed "harmless." Finally, Part VI addresses implementation details and practical objections.

\section{The Failure of Current Remedies for Prosecutorial Misconduct}

Prosecutorial misconduct has been a widespread and widely criticized problem in the U.S. criminal justice system for decades. ${ }^{17}$ "Misconduct" is. a term

they would similarly abstain from sanctioning police, especially given the Supreme Court's recent suggestion that police departments can be trusted to handle discipline for Fourth Amendment violations internally. See Hudson v. Michigan, 547 U.S. 586, 598-99 (2006).

17. See, e.g., United States v. Modica, 663 F.2d 1173, 1182-83 (2d Cir. 1981) (noting the court's "oft-expressed concern over the frequency with which improper prosecution" occurs); Albert W. Alschuler, Courtroom Misconduct by Prosecutors and Trial Judges, 50 Tex. L. Rev. 629, 631 (1972); Michael D. Cicchini, Prosecutorial Misconduct at Trial, 37 Seton HaLl L. Rev. 335, 369 (2007) (noting that "prosecutorial misconduct is wide-spread and has infected every aspect of the criminal trial."); Alexandra White Dunahoe, Revisiting the Cost-Benefit Calculus of the Misbehaving Prosecutor: Deterrence Economics and Transitory Prosecutors, 61 N.Y.U. ANN. SURv. AM. L. 45, 46 (2005) 
with no fixed meaning. I use it broadly to refer to any prosecutorial actions violating defendants' constitutional or otherwise substantial rights. Examples include failure to disclose exculpatory evidence, race and sex discrimination in jury selection, inflammatory in-court statements, deliberate attempts to get excluded information before the jury, and undue delays that deny a speedy trial. ${ }^{18}$ In principle, such conduct can trigger strong judicial remedies for the defendant-mistrial, appellate reversal of conviction, or dismissal of chargesand direct sanctions against the prosecutor:

Yet these strong remedies share a common defect: they are rarely invoked. ${ }^{19}$ For instance, at the trial level, courts rarely grant mistrials for in-court misconduct. ${ }^{20}$ They rely instead on curative instructions, which studies show are ineffective or even counterproductive, calling attention to the very thing they tell juries to ignore. ${ }^{21}$ Moreover, instructions do not deter prosecutors from attempting to get away with misconduct—even if instructions work, the prosecutor will generally not end up worse off than if she had not misbehaved.

Likewise, consider the principal appellate remedy for procedural violations: reversal of conviction, usually followed by retrial. This remedy is so rarely granted in noncapital cases that some commentators have referred to it as a "dysfunctional" remedy for misconduct. ${ }^{22}$ The usual reason for denying reversal is the harmless error doctrine. ${ }^{23}$ Prosecutorial misconduct is almost always deemed harmless, even quite serious misconduct such as deliberate withholding of exculpatory evidence. ${ }^{24}$ As Judge Posner has written for the Seventh Circuit,

(noting that prosecutorial misconduct has tripled in the last decade, according to the Department of Justice); Peter A. Joy, The Relationship Between Prosecutorial Misconduct and Wrongful Convictions: Shaping Remedies for a Broken System, 2006 WIS. L. REv. 399, 399-400 (citing study documenting hundreds of homicide cases that were reversed due to prosecutorial misconduct); Tracey L. Meares, Rewards for Good Behavior: Influencing Prosecutorial Discretion and Conduct with Financial Incentives, 64 Fordham L. Rev. 851, 890 (1995); Walter W. Steele, Jr., Unethical Prosecutors and Inadequate Discipline, 38 Sw. L.J. 965, 966, 975 (1984).

18. See Berger v. United States, 295 U.S. 78, 84-85 (1935) (giving examples of prosecutorial misconduct and defining it as "overstep[ing] the bounds of ... propriety and fairness").

19. E.g., Cicchini, supra note 17, at 336; Joy, supra note 17, at 425-26; Meares, supra note 17, at 893-98.

20. E.g., Cicchini, supra note 17 , at 336.

21. E.g., id. at 363-64; see Dennis J. Devine et al., Jury Decision Making: 45 Years of Empirical Research on Deliberating Groups, 7 Psychol. PuB. PoL'y \& L. 622, 666-67 (2001) (reviewing empirical evidence); J. Alexander Tanford, The Law and Psychology of Jury Instructions, 69 NeB. L. REv. 71, 95-108 (1990).

22. Steele, supra note 17, at 976-77; accord Alschuler, supra note 17 , at 645,647 ; $c f$. United States v. Modica, 663 F.2d 1173, 1184 (2d Cir. 1981) ("Despite numerous threats to reverse convictions for prosecutorial misconduct, federal courts have seldom invoked that sanction.").

23. See infra section V.C.

24. E.g., Francis A. Allen, A Serendipitous Trek Through the Advance-Sheet Jungle: Criminal Justice and the Courts of Review, 70 IowA L. REv. 311, 333 (1985); Alschuler, supra note 17, at 659; Meares, supra note 17, at 900-01; see William M. Landes \& Richard A. Posner, Harmless Error, 30 J. LEGAL STUD. 161, 182-92 (2001) (reviewing 1222 criminal procedure cases-not limited to prosecutorial misconduct-and finding that courts invoked the harmless error doctrine in $87 \%$ of them, with $45 \%$ finding harmless error and $42 \%$ finding that any error, if it existed, was harmless). 
the doctrine renders procedural protections "like the grapes of Tantalus"forever just out of defendants' reach-and seriously undermines deterrence of misconduct. ${ }^{25}$ Moreover, weakened appellate enforcement may encourage trial courts to tolerate misconduct themselves. ${ }^{26}$

The harmless error doctrine is not the only obstacle to effective appellate remedies. For some categories of prosecutorial misconduct, the Supreme Court has established strong automatic remedies without harmless error review-and lower courts appear to have responded by avoiding recognizing misconduct in the first place. For instance, the Supreme Court's jurisprudence on prosecutorial race discrimination in jury venire selection, beginning with Batson v. Kentucky, has been read to require automatic reversal. ${ }^{27}$ Scholars have demonstrated, however, that since the establishment of this remedy, courts have narrowed the circumstances under which they will find race discrimination, "combining a deferential standard of appellate review with a sweeping scope of permissible neutral explanations for prosecutorial strikes." 28

Courts have similarly circumscribed the scope of the Speedy Trial Clause of the Sixth Amendment ever since the Supreme Court held that dismissal with prejudice is "the only possible remedy" for violations. ${ }^{29}$ Scholars and courts have recognized that this extreme remedy dissuades trial and appellate judges from finding violations, even in the face of "shockingly long delays." Susan Herman concludes on the basis of a comprehensive review of the case law, the "severity of the remedy ... has had a profound effect on the development of speedy trial jurisprudence."31 Ultimately, "dismissal is granted in a tiny fraction of the thousands of constitutional speedy trial claims brought every year." ${ }^{32}$

These examples illustrate a broader phenomenon documented by a wealth of scholarship in criminal procedure and other fields: if the remedy for a rights violation is undesirable, courts will find ways to avoid granting it, such as narrowing the underlying right. ${ }^{33}$ Daryl Levinson calls this phenomenon "reme-

25. United States v. Pallais, 921 F.2d 684, 691-92 (7th Cir. 1990).

26. See Kate Stith, The Risk of Legal Error in Criminal Cases: Some Consequences of the Asymmetry in the Right to Appeal, 57 U. CHI. L. Rev. 1, 48 (1990).

27. Batson v. Kentucky, 476 U.S. 79, 100 (1986).

28. Pamela S. Karlan, Race, Rights, and Remedies in Criminal Adjudication, 96 Mrch. L. Rev. 2001, 2005, 2015, 2021 (1998); see Robin Charlow, Tolerating Deception and Discrimination After Batson, 50 STAN. L. REv. 9, 16 (1997); infra section V.B.

29. Barker v. Wingo, 407 U.S. 514, 522 (1972); see infra section V.A.

30. Anthony G. Amsterdam, Speedy Criminal Trial: Rights and Remedies, 27 Stan. L. Rev. 525, 539 (1975); see United States v. Strunk, 467 F.2d 969, 972 (7th Cir. 1972), rev'd 412 U.S. 434 (1973); Susan N. Herman, The Right to a Speedy and Public Trial 230 (2006); Akhil Reed Amar, Sixth Amendment First Principles, 84 Geo. L.J. 641, 646 (1996).

31. HERMAN, supra note 30, at 212.

32. Id. at 231 .

33. E.g., Barry Friedman, When Rights Encounter Reality: Enforcing Federal Remedies, 65 S. CAL. L. REv. 735, 738 (1992); Neal Kumar Katyal, Legislative Constitutional Interpretation, 50 DuKE L.J. 1335, 1370 (2001); Daryl J. Levinson, Rights Essentialism and Remedial Equilibration, 99 ColUM. L. 
dial deterrence," a phrase I borrow: the high cost of remedies deters courts from vindicating rights. ${ }^{34}$ For instance, numerous scholars have argued that after Mapp v. Ohio established the Fourth Amendment exclusionary rule, lower courts chipped away at the scope of the Fourth Amendment. ${ }^{35}$ Similarly, Stephen Clymer argues that in order to avoid dismissing indictments, courts have made it almost impossible to prove discriminatory selective prosecution. ${ }^{36}$ Scholars have identified analogous phenomena in a variety of other areas, such as $\operatorname{tax}^{37}$ and administrative law. ${ }^{38}$

But why are reversal, mistrial, and dismissal seen as high-cost remedies? Reversals and mistrials impose the cost of retrial on the public, the parties and witnesses, and the court system, a concern frequently cited by courts ${ }^{39}$ and by commentators. ${ }^{40}$ They may not be followed by reconviction, resulting in guilty defendants being set free. ${ }^{41}$ Judges may see such remedies as creating undue windfalls. ${ }^{42}$ In addition, almost all state judges are elected, ${ }^{43}$ and voters may resent the costs of retrials or perceive them as unacceptable delays in justice. ${ }^{44}$

Rev. 857, 884-85 (1999). I have elsewhere described a number of examples of remedial deterrence in international courts. Starr, supra note 6, at 710-36.

34. Levinson, supra note 33, at 884-85.

35. E.g., Akhil Reed Amar, Fourth Amendment First Principles, 107 HARv. L. Rev. 757, 799 (1994); Calabresi, supra note 1, at 112; Kamisar, supra note 12, at 133-34; Christopher Slobogin, Why Liberals Should Chuck the Exclusionary Rule, 1999 U. IL. L. Rev. 363, 401-03; see also J.A.E. Pottow, Constitutional Remedies in the Criminal Context: A Unified Approach to Section 24 (Part II), 44 CRIM. L.Q. 34, 64-68 (2000) (describing remedial deterrence in context of exclusion of coerced selfincriminatory evidence in Canada).

36. Stephen D. Clymer, Unequal Justice: The Federalization of Criminal Law, 70 S. CAL. L. REv. $643,683,736$ (1997).

37. See JACk B. Siegel, A Desktop Guide for Nonprofit Directors, Officers, and Advisors 240 (2006) (noting that under a regime in which the sole penalty for a nonprofit's regulatory violation was loss of tax-exempt status, regulators could not win cases, necessitating the adoption of less harsh intermediate sanctions).

38. See Daniel B. Rodriguez, Of Gift Horses and Great Expectations: Remands Without Vacatur in Administrative Law, 36 ARIz. ST. L. REv. 599, 601 (2004) (arguing that the availability of a less intrusive remedy, remand without vacatur, "facilitates the use of more aggressive judicial scrutiny" of agency decisions).

39. E.g., United States v. Mechanik, 475 U.S. 66, 73 (1986); United States v. Tumer, 474 F.3d 1265, 1275 (11th Cir. 2007), cert. denied, 128 S. Ct. 867 (2008); United States v. Modica, 663 F.2d 1173, 1184 (2d Cir. 1981); Stringer v. Mississippi, 627 So. 2d 326, 330 (Miss. 1993).

40. Alschuler, supra note 17, at 663; Dunahoe, supra note 17, at 95; Richard A. Posner, Excessive Sanctions for Government Misconduct in Criminal Cases, 57 WaSH. L. Rev. 635, 644 (1982).

41. Retrial is precluded by the Double Jeopardy Clause when the prosecutor's misconduct was intended to trigger a mistrial. Oregon v. Kennedy, 456 U.S. 667,679 (1982). In other cases, retrial might be precluded in practice by loss of evidence or it might result in an acquittal (even if the defendant is in fact guilty). See Posner, supra note 40, at 644.

42. See, e.g., Luce v. United States, 469 U.S. 38, 42 (1984) (describing the "windfall of automatic reversal"); Kansas v. Bolen, 13 P.3d 1270, 1274 (Kan. 2000) (noting that "dismissal with prejudice may serve to punish the public and provide a windfall for the defendant"); North Dakota v. Tweeten, 679 N.W.2d 287, 291-94 (N.D. 2004) (same).

43. David E. Pozen, The Irony of Judicial Elections, 108 Colum. L. REv. 265, 266 (2008).

44. See Evitts v. Lucey, 469 U.S. 387, 405-06 (1985) (Burger, C.J., dissenting) ("Few things have . . contributed more to lowered public confidence in the courts, than the interminable appeals, the retrials, and the lack of finality."). 
Voters also may ignore the possibility of retrial and simply perceive reversal or mistrial (like dismissal) as letting a criminal off the hook..$^{45}$

To judges, then, it may seem like a better option to let the misconduct slide. As Stanley Fisher put it: "Because courts are understandably reluctant to reverse convictions, even if the prosecutor's conduct has been egregiously unethical," they "may strain to excuse or overlook the prosecutor's questionable conduct" or deem it "'harmless." 46 In short, when faced with all-or-nothing remedial choices, courts tend to choose nothing.

Nor is there much hope for solving the problem via direct sanctions against the prosecutor-contempt, fines, and referral for bar discipline-as some scholars have proposed.$^{47}$ Courts already have these options but are even more reluctant to impose them than to reverse convictions. ${ }^{48}$ Indeed, they rarely even identify misbehaving prosecutors by name in published opinions. ${ }^{49}$ Judges, it appears, simply have no appetite for directly imposing personal or professional penalties on the prosecutors with whom they regularly interact. They may also wish to avoid the risk of over-deterring appropriate prosecutorial zeal-the concern that underlies prosecutors' civil immunity. ${ }^{50}$

Similarly, the solution is unlikely to be found in proposals for professional discipline led by bar associations. ${ }^{\text {s1 }}$ Bar associations are notoriously lax in policing the ethics of any of their members, particularly prosecutors, who virtually never face discipline even when courts identify misconduct. ${ }^{52}$ Scholars

45. See, e.g., Patricia L. Garcia, Austin College Welcomes Texas Supreme Court, 70 TEx. B.J. 446, 446 (2007) (observing that a Tennessee state supreme court chief justice was unseated because "the public perceived [a controversial] ruling to be a reversal" even though it was really a remand); Michael Hall, And Justice For Some, Tex. Monthly, Nov. 1, 2004, at 154; R.G. Ratcliffe, Opinions Divided On Judge in Dispute Over Condemned Man, Houston Chron., Oct. 10, 2007, at B1; Dennis B. Roddy, Judges Can't Dismiss Popular Opinion, PttT. Post-GAzETte, July 14, 1991, at B1.

46. Stanley Z. Fisher, In Search of the Virtuous Prosecutor, 15 AM. J. CRIM. L. 197, 212-13 (1988).

47. E.g., Peter J. Henning, Prosecutorial Misconduct and Constitutional Remedies, 77 Wash. U. L.Q. 713, 828-31 (1999); Kelly Gier, Note, Prosecuting Injustice: Consequences of Misconduct, 33 AM. J. CrIM. L. 191, 205-12 (2006).

48. See Alschuler, supra note 17, at $633,673-74$ (stating that a survey of twenty-five years of reported decisions found no examples of courts imposing sanctions on prosecutors); Dunahoe, supra note 17 , at $84 \mathrm{n} .146$ (noting that the use of contempt sanctions has remained extremely infrequent in the decades since Alschuler's article); id. at 83-84 (noting that other criminal sanctions are available but essentially never used); Meares, supra note 17, at 893-97; Steele, supra note 17, at 978, 981. In contrast, the Center for Public Integrity's study of appellate opinions nationwide between 1970 and 2003 found 2012 cases in which courts granted the defendant a remedy for prosecutorial misconduct. See Steve Weinberg, Breaking the Rules: Who Suffers When a Prosecutor is Cited for Misconduct?, THE CTR. FOR PUB. INTEgRITY, June 26, 2003, available at http://www.publicintegrity.org/pm/ default.aspx?sID=main (noting, however, that this still means reversals are a "relative rarity").

49. United States v. Modica, 663 F.2d 1173, 1185-86 \& n.7 (2d Cir. 1981); Dunahoe, supra note 17, at 72 ; Henning, supra note 47 , at $830-31$.

50. See Imbler v. Pachtman, 424 U.S. 409, 427-28 (1976); Dunahoe, supra note 17, at 75.

51. E.g., Joy, supra note 17, at 427; Steele, supra note 17, at 982-88; Gier, supra note 47, at 205.

52. Bennett L. Gershman, The New Prosecutors, 53 U. PTTT. L. Rev. 393, 445 (1992) ("[D]espite the recognized frequency of misconduct by prosecutors in argument to the jury, this writer has found only one decision" in which such conduct resulted in discipline.); Meares, supra note 17, at 899; Steele, supra note 17, at 966, 981-82; Gier, supra note 47, at 201. 
have suggested that bar associations do "not wish to alienate" powerful and prestigious prosecutors. ${ }^{53}$ And for other lawyers, bringing ethics complaints against prosecutors may amount to "career suicide." 54

Some scholars have proposed that defendants who suffer constitutional wrongs be empowered to sue prosecutors in civil court. ${ }^{55}$ But even if the current rule of absolute prosecutorial immunity were changed ${ }^{56}$ damages probably would not be an effective deterrent. Criminal defendants do not make appealing civil plaintiffs ${ }^{57}$ and may also have a hard time quantifying damages. ${ }^{58}$ In light of the dubious prospects of recovery, most might not bother to sue, especially given the high costs of litigation, the poverty of most criminal defendants, and the lack of appointed counsel for civil suits. ${ }^{59}$ Even if defendants did sue and win, most states' laws indemnify individual prosecutors-otherwise, over-deterrence might be a serious concern. ${ }^{60}$ And although the government would take a financial hit if successfully sued, it is unclear whether that threat would change behavior. Government agencies do not predictably respond to financial incentives the way private actors do; their budgets are under political control and can be increased to offset losses, and they may be more motivated by votes than by dollars. ${ }^{61}$

Several scholars have proposed eliminating courts' discretion in responding to misconduct and making remedies or sanctions automatic. ${ }^{62}$ Such approaches carry some intuitive appeal because part of the problem seems to be a lack of judicial backbone. But even if courts should take these steps more often, requiring them to do so would be risky. The lesson of the literature on remedial deterrence is that when remedial discretion is taken away, courts tend to respond by narrowing rights. If a court is forced to sanction prosecutorial misconduct too harshly, it may avoid recognizing misconduct at all.

\section{Sentence Reduction as an Alternative Remedy}

In light of the remedial deterrence problem, the best solution to prosecutorial misconduct may not be "stronger" remedies at all. Rather, it may be better to

53. Gershman, supra note 52 , at 445.

54. Gier, supra note 47 , at 201.

55. See Alschuler, supra note 17 , at 669 .

56. See Imbler v. Pachtman, 424 U.S. 409, 427-28 (1976).

57. See, e.g., Alschuler, supra note 17, at 670; Daniel J. Meltzer, Deterring Constitutional Violations by Law Enforcement Officials: Plaintiffs and Defendants as Private Attorneys General, 88 CoLuM. L. REv. 247, 284 (1988).

58. See Meltzer, supra note 57, at 284.

59. Meares, supra note 17 , at $892-93$.

60. See Posner, supra note 40 , at 637 . For some forms of misconduct, there may be little cost to overdeterrence, however. See Dunahoe, supra note 17, at 88 (discussing disclosure).

61. Daryl J. Levinson, Making Government Pay: Markets, Politics, and the Allocation of Constitutional Costs, 67 U. ChI. L. Rev. 345, 361-62, 420 (2000).

62. See Cicchini, supra note 17, at 336 (proposing requiring mistrial, plus dismissal with prejudice if misconduct was intentional); Joy, supra note 17, at 427; Kenneth Williams, The Death Penalty; Can It Be Fixed?, 51 CATH. U. L. REv. 1177, 1200 (2002). 
give courts the option of a lesser remedy-one which, if it is more likely to be invoked, would actually be more effective. Here, I propose sentence reduction as such an alternative. Section A gives an overview of the proposed remedy, and section $\mathrm{B}$ argues that courts will be willing to grant it.

\section{A. THE PROPOSAL}

Trial and appeals courts should be empowered to grant sentence reduction as a remedy for prosecutorial misconduct when the reliability of the conviction has not been affected. Sentence reduction might also be permitted as a form of habeas corpus relief. It could be used to address misconduct at trial, during pretrial proceedings, or (as in the recent Dicus case) relating to plea-bargaining or breaches of plea agreements, as well as misconduct relating to sentencing itself. The reduction could be a fixed amount, percentage of the sentence, or number of levels in a sentencing guidelines scheme, or the court could be permitted to tailor it to the violation. The legislature or sentencing commission could set forth a few different options for the magnitude of the reduction, with examples of what misconduct might qualify for each. Such guidance could help to reduce disparity among courts' approaches while still allowing flexibility in responding to particular violations. ${ }^{63}$

Under this scheme, factors affecting the magnitude of the appropriate reduction in a given case could include the nature of the rights violated, the violation's effect on the defendant, the prosecutor's mental state, and the prosecutor's or the office's recidivism. Relatively minor examples of misconduct could trigger just a symbolic reduction, while very serious examples could trigger significant reductions. ${ }^{64}$ Reductions should be at least sufficient to compensate the defendant for any non-conviction-related harm she suffered, and bigger if necessary to deter or condemn misconduct effectively. ${ }^{65}$ For instance, a bigger reduction might be required to deter or condemn repeat offenders, even though the particular defendant receiving the reduction has suffered no additional harm due to the prosecutor's prior misconduct.

I do not suggest that sentence reduction would be appropriate in all cases of prosecutorial misconduct. Sometimes, dismissal of charges, mistrial, or appellate reversal may be necessary to avoid a risk of wrongful conviction. Sentence reduction would be plainly inadequate to serve this purpose, and I do not propose it, at least not as the sole remedy, ${ }^{66}$ when prosecutorial misconduct

63. See infra Part VI (discussing the need to balance flexibility with reduction of disparity); Starr, supra note 8, at 33 (developing this proposal in the federal context).

64. If a short base sentence has already been completely served when the appeal is decided, sentence reduction would not be a viable appellate remedy. In such cases, courts could perhaps be empowered instead to take steps to mitigate the collateral consequences of the conviction, possibly including vacating the conviction entirely even if the error was "harmless." See infra notes 211-12 and accompanying text (likewise suggesting this alternative for cases involving rehabilitative sentences).

65. See infra section IV.D (discussing valuation difficulties associated with such tailoring).

66. Sentence reduction could also supplement reversal-the defendant could be entitled to a reduction if reconvicted to compensate for the stress and inconvenience of being tried twice. This 
undermines the court's confidence in the factual validity of the conviction.

But not every criminal procedure remedy serves that innocence-protection rationale. Even when misconduct has not affected the verdict in the case at hand, effective remedies may be necessary for several reasons: to deter misconduct that could harm defendants in other cases, to compensate the defendant for non-conviction-related harms, and to send a message condemning the misconduct and reaffirming the defendant's rights and dignity. As I argue in Parts III and IV, sentence reduction can effectively serve these functions and thus is an appropriate remedy when a court concludes that the misconduct did not affect the trial verdict. My proposal would thus provide a new remedy for so-called "harmless error" cases, which currently trigger no remedy at all. On the other hand, it also would allow for a "lesser" remedial alternative for some of the categories of misconduct that currently trigger automatic strong remedies; in Part V, I consider the examples of Batson and speedy trial violations.

\section{B. SENTENCE REDUCTION AND REMEDIAL DETERRENCE}

If courts avoid issuing the various currently available remedies for prosecutorial misconduct, why should we expect them to be willing to order sentence reductions? After all, sentence reduction also entails political risks for elected judges, and, further, courts may see it as interfering with the main sentencing goals of punishing, condemning, and preventing crime. ${ }^{67}$

Still, for several reasons, courts are likely to be much more willing to grant sentence reductions than current windfall remedies. Perhaps most importantly, sentence reduction would not require the time and expense of retrial, which may be the biggest disincentive to mistrials and to reversals of convictions. ${ }^{68}$ Moreover, courts have sometimes expressed frustration at the absence of effective but non-windfall remedies for prosecutorial misconduct, ${ }^{69}$ suggesting that at least some courts would welcome an intermediate remedy, especially if they could control the magnitude. Indeed, the recent Dicus decision explicitly stated that sentence reduction "may be more palatable for the court to impose than other, more typical remedies for prosecutorial misconduct" because it does not amount to a windfall. ${ }^{70}$ And courts might even consider the post-reduction sentence to be a fairer one for the underlying crime. Surveys consistently show that most

Article does not focus on that possibility but instead on sentence reduction as an alternative to remedies that courts are rarely willing to invoke; obviously, using it as an additional remedy would not solve this remedial deterrence problem.

67. See infra section IV.E (discussing sentencing objectives and remedial sentence reduction).

68. See supra notes $39-41$ and accompanying text. This efficiency improvement would be a major advantage even if a separate resentencing hearing were required. See United States v. Williams, 399 F.3d 450, 456 (2d Cir. 2005) (noting that such hearings are "brief" and cost "far less" than retrials); Charles A. Wright, Federal Practice and Procedure $\$ 856$, at 511-12 (2004).

69. See United States v. Pallais, 921 F.2d 684, 691-92 (7th Cir. 1990); United States v. Modica, 663 F.2d 1173, 1182-86 (2d Cir. 1981).

70. United States v. Dicus, 579 F. Supp. 2d, 1142, 1160-61 (N.D. Iowa 2008) (citing and agreeing with earlier draft of this Article). 
judges believe that modern sentencing schemes are overly harsh and generally choose the lowest available sentence. ${ }^{71}$

Even if courts believe sentence reductions are desirable and low-cost for all of these reasons, there is a possibility that political pressures would deter elected judges from granting them. ${ }^{72}$ However, this problem is likely to be much less severe than it is for the current, more drastic remedies. Sentence reduction would not "let criminals off scot-free," nor would it impose the costs of retrial on the public. ${ }^{73}$ Because the court could tailor the reduction's magnitude to the seriousness of the misconduct, the remedy need not be perceived as a disproportionate judicial response, meaning that blame for it should go to the prosecutor, not the court. ${ }^{74}$ In many cases, the reduction could be quite small and would thus likely be less controversial. In Dicus, for instance, the court issued a modest reduction from the top to the bottom of the Sentencing Guidelines range, or from eighty-seven to seventy months-not a trivial reduction from the defendant's perspective, but not a drastic one either. ${ }^{75}$

If courts nonetheless proved reluctant to grant reductions, legislatures could consider making some degree of reduction mandatory. Mandatory remedial requirements are risky. As discussed in Part I, they may drive courts to narrow their interpretations of rights. However, if the court would otherwise want to grant the remedy but for its political risks, making it mandatory could provide necessary political cover. Sentence reduction is currently untested, so there are unknowns concerning judicial incentives. It may be necessary to experiment with different approaches to make it work best.

Because of the remedial deterrence problem, I do not suggest that sentence reduction should automatically trigger direct sanctions against misbehaving prosecutors, as Calabresi, as well as Caldwell and Chase, propose for police officers who commit Fourth Amendment violations. ${ }^{76}$ As discussed in Part I, courts are extremely unwilling to issue direct sanctions against prosecutors. If so, it would be counterproductive to make such a sanction the automatic result of a sentence reduction: courts could then only avoid the direct sanction by declining to issue the reduction. Instead, an effective sentence reduction scheme must stand on its own merits, rather than merely being a trigger for the "real" sanction as it is under the Fourth Amendment proposals. For the scheme to work, the fear of sentence reduction itself must adequately deter prosecutorial misconduct. The next Part considers whether it can do so.

71. See Frank O. Bowman, III \& Michael Heise, Quiet Rebellion? Explaining Nearly a Decade of Declining Federal Drug Sentences, 86 Iowa L. Rev. 1043, 1107 \& n.252 (2001); Calabresi, supra note 1, at 116; Marc L. Miller, Domination \& Dissatisfaction: Prosecutors as Sentencers, 56 STaN. L. Rev. $1211,1214-15,1222-23,1236-37$ (2004).

72. See infra notes $114-16$ and accompanying text.

73. Cf. Starr, supra note 6 , at 717 (discussing the Rwanda Tribunal's turn to sentence reduction as a politically acceptable alternate remedy when release posed risk of catastrophic political backlash).

74. See infra section IV.C (discussing role of proportionality in public acceptance of remedies).

75. Dicus, 579 F. Supp. 2d at 1158-61.

76. See supra note 11 and accompanying text. 


\section{Sentence Reduction as a Deterrent: Prosecutors' Incentives}

The effectiveness of a remedy in deterring prosecutorial misconduct turns on two factors: the probability that it will be invoked in the event of misconduct and the cost it imposes on prosecutors if it is invoked. ${ }^{77}$ The economic literature on deterrence in other contexts strongly suggests that the first factor is by far the most important. ${ }^{78}$ When deterrent schemes rely on large penalties to compensate for a very low probability of punishment, they tend to fail. ${ }^{79}$ And indeed, courts and commentators have recognized that although reversals and mistrials are costly to prosecutors, their rarity greatly undermines their deterrent effect. ${ }^{80}$ If courts are significantly more likely to grant sentence reductions than the present remedies, that factor should make them a more effective deterrent even if they impose lesser costs on prosecutors.

Still, even a high likelihood of sentence reduction can only deter misconduct if it imposes costs on prosecutors that outweigh the gains misconduct offers. ${ }^{81}$ In this Part, I examine prosecutorial incentives and conclude that sentence reduction would impose sufficient costs. No existing literature gives a comprehensive account of prosecutors' various incentives. ${ }^{82}$ But these incentives are illustrated, albeit in a piecemeal fashion, by a large body of scholarship on plea bargaining, charging, and other prosecutorial behavior. This Part draws insights from that literature into how prosecutors might respond to the risk of remedial sentence reduction. Section A addresses the gains prosecutors seek through misconduct; section $\mathrm{B}$ considers the costs imposed by sentence reduction through the lenses of several different theoretical models of prosecutorial incentives; and section $\mathrm{C}$ reviews the existing empirical evidence about prosecutors' sentencing-related behavior.

\section{A. THE GAINS OFFERED BY MISCONDUCT}

Before considering the costs that sentence reduction imposes on prosecutors, a word is in order about the gains they seek from misconduct-it is the

77. See, e.g., Frank H. Easterbrook, Criminal Procedure as a Market System, 12 J. LeGAL Stud. 289, 292 (1983) (discussing deterrence of crime).

78. E.g., Gary Becker, Crime and Punishment: An Economic Approach, 76 J. Pol. Econ. 169, 176 n.12 (1968); Dan M. Kahan, Social Influence, Social Meaning, and Deterrence, 83 VA. L. REv. 349, 380 \& n.112 (1997) (citing studies).

79. See Edward K. Cheng, Structural Laws and the Puzzle of Regulating Behavior, 100 Nw. U. L. Rev. 655, 660 (2006).

80. See United States v. Modica, 663 F.2d 1173, 1183 (2d Cir. 1981); Alschuler, supra note 17, at 647; Cicchini, supra note 17, at 348; Meares, supra note 17, at 900-01; Steele, supra note 17, at 976-77; see also infra section V.C (discussing scholarship on harmless error review).

81. Oren Bick, writing on sentence reduction in Canada, has questioned its deterrent value, although he provides no empirical basis for his position and does not focus on prosecutors, specifically. Oren Bick, Remedial Sentence Reduction, 51 CRIM. L.Q: 199, 221 (2006).

82. See Dunahoe, supra note 17, at 59; Daniel C. Richman, Old Chief v. United States: Stipulating Away Prosecutorial Accountability?, 83 VA. L. Rev. 939, 942; 966-67 (1997); William J. Stuntz, The Uneasy Relationship Between Criminal Procedure and Criminal Justice, 107 YALE L.J. 1, 46 n.158 (1997). 
comparison between expected costs and expected gains that determines the remedy's deterrent effect. Usually, deliberate misconduct is committed to increase the chance of conviction. ${ }^{83}$ This is true even in cases in which the misconduct can be identified as "harmless" ex post. Such misconduct is committed because of a perceived benefit, even if it ultimately turns out to bring the prosecutor no gain-when deciding to commit misconduct, prosecutors have incomplete information about how the trial will go. ${ }^{84}$

But if misconduct is driven by a desire for convictions, how can a remedy short of reversal deter it? I concede that sentence reduction cannot accomplish perfect deterrence, nor can any other remedial scheme-sometimes the gains from misconduct will be too tempting. For instance, suppose a "bad actor" prosecutor were $100 \%$ certain that misconduct would make the difference between winning and losing a case. It would not be possible to deter her from committing the misconduct via a threat of sentence reduction alone because, even if that remedy were imposed, it would leave her gain partially intact.

But the situation facing prosecutors is rarely so black and white, especially in the kinds of cases that are the focus of this Article, namely those in which the misconduct is ultimately found not to have affected the verdict. In such cases, it is more likely that a prosecutor would expect misconduct to increase the likelihood of conviction by a small amount-say from $75 \%$ to $85 \%$. If so, the expected gain would only be $10 \%$ of the benefit of a conviction. Thus, a threat of sentence reduction could deter the misconduct, provided that the cost of the reduction and likelihood of imposition were sufficient to make the expected penalty outweigh that smaller expected gain.

In addition, the scheme I propose does not leave sentence reduction as the only possible remedy. Rather, it maintains reversal as the required appellate remedy for cases in which misconduct has affected the verdict. Sentence reduction would apply only in cases in which the verdict was unaffected-so it would impose a cost that, if the harmlessness determination is accurate, is unaccompanied by a prosecutorial gain. Prosecutors might still gain due to misconduct if courts wrongly deem errors harmless, but this is also true under current all-or-nothing remedial schemes. At least when sentence reduction is granted for errors deemed harmless, the prosecutor would not retain all the benefits of a conviction in such instances. Likewise, when trial courts identify prosecutorial misconduct, mistrial would remain required if the court determines that the misconduct rendered a fair trial impossible; in other cases, sentence reduction would be added to existing interlocutory remedies like

83. See Gershman, supra note 52, at 430; Alicia M. Hilton, Altematives to the Exclusionary Rule After Hudson v. Michigan: Preventing and Remedying Police Misconduct, 53 VILL. L. REv. 47, 80 (2008) (discussing studies).

84. See Gershman, supra note 52 at 430 . ("That prosecutors actually do assess the risks and benefits associated with misconduct is an intuitively, anecdotally, and empirically well-founded conclusion."). Some misconduct may, however, be motivated by non-conviction-related reasons, including idiosyncratic factors like personal animus toward defense counsel. 
curative instructions. The prosecutor thus would still be deprived of all the gains of misconduct in any case in which current trial court remedies would deprive her of them and would be rendered worse off in the cases in which the current system allows her to preserve those gains.

This Article focuses principally on deliberate misconduct, but some serious violations of defendants' rights result from prosecutors' negligence-for instance, the careless failure to turn over exculpatory evidence. A sentence reduction scheme could apply to such misconduct, encouraging prosecutors to be more careful. The costs imposed by sentence reduction, discussed below, would be essentially the same whether the reduction is imposed for deliberate or negligent misconduct. But the "gain" is different for non-deliberate misconduct-it is whatever the prosecutor prefers to spend time on rather than taking extra care to protect defendants' rights. Using sentence reduction to respond to simple negligence does carry a potential risk of remedial deterrence: courts may try to avoid imposing reductions by not recognizing misconduct if they sympathize with overworked prosecutors' mistakes. To reduce that risk, the remedy could be triggered at some intermediate threshold, like gross negligence; alternatively, simple negligence could be met with only very small reductions.

In any event, the potential gains from undetected misconduct will vary from case to case, and I do not give an extended account of those gains here because they will be the same regardless of the remedial scheme. What differ are the cost of penalties for misconduct and the likelihood of their imposition. I have argued above that sentence reduction is more likely to be imposed than current "stronger" remedies; the remainder of this Part compares the cost imposed by sentence reduction with those imposed by current remedies.

\section{B. MODELS OF PROSECUTORIAL INCENTIVES}

Although prosecutors' interests vary, there are many reasons to believe most prosecutors would be deterred by a sentence reduction scheme. Such reductions would impair several different prosecutorial objectives. Here, I assess the costs of sentence reduction from the perspective of several different ideal-typical prosecutors, each representing one of those different objectives.

\section{Deterring Crime}

First, consider a hypothetical prosecutor, McGruff, motivated solely by the desire to reduce crime as much as the office's resources permit. Many law-andeconomics scholars have assumed that this is what motivates prosecutors, ${ }^{85}$ and it is probably safe to say that this is indeed a significant part of many prosecu-

85. E.g., Scott Baker \& Claudio Mezzetti, Prosecutorial Resources, Plea Bargaining, and the Decision to Go to Trial, 17 J.L. EcoN. \& ORG. 149, 155 (2001); Easterbrook, supra note 77, at 295-96; William M. Landes, An Economic Analysis of the Courts, 14 J.L. \& EcoN. 61, 63 (1971); Stephen F. Smith, Proportionality and Federalization, 91 VA. L. Rev. 879, 928 n.123 (2005). 
tors' motivations. ${ }^{86}$ Prosecutors, after all, have chosen careers in law enforcement, usually over higher-paying private-sector jobs. ${ }^{87}$ Moreover, their superiors generally have a strong political interest in reducing crime, ${ }^{88}$ and that interest may influence line prosecutors. ${ }^{89}$

McGruff would generally prefer longer sentences to shorter ones because he seeks "to obtain the maximum deterrence from his available resources." 90 Deterrence depends on the probability and magnitude of the penalty, so McGruff must "maximize the expected number of convictions weighted by their respective" sentences. ${ }^{91}$ In short, McGruff seeks to maximize expected sentenceyears. He will accept shorter sentences pursuant to plea bargains to obtain certainty of conviction and to save resources (allowing him to pursue more sentence-years in other cases). But once he has decided to pursue a case to trial, a reduced sentence is plainly a setback. ${ }^{92}$

\section{Efficient Case Processing}

Second, consider another hypothetical prosecutor, Sleepy, who is less publicminded-she is motivated entirely by the desire to maximize her leisure time without losing her job, and thus, she seeks to dispose of cases as quickly as she is able. Although it would be unfair to suggest that many prosecutors are quite like Sleepy, most presumably do consider efficient docket management to be an important part of the job (including the altruistic McGruff). ${ }^{93}$ So Sleepy is a useful ideal type.

Sleepy seeks to induce as many defendants as possible to plead guilty on terms that are minimally sufficient to satisfy her superiors. But defendants will not accept such terms unless they believe that, should they refuse, Sleepy will

86. See Edward L. Glaeser et al., What Do Prosecutors Maximize?: An Analysis of the Federalization of Drug Crimes, 2 AM. L. \& ECON. REv. 259, 260-61, 286 (2000) (finding evidence suggesting prosecutors maximize both social welfare and career advancement); Anthony C. Thompson, It Takes a Community to Prosecute, 77 Notre Dame L. Rev. 321, 330 (2002). Prosecutors no doubt also have personal interests that may diverge from the public interest in deterrence, see, e.g., Keith N. Hylton \& Vikramaditya Khanna, A Public Choice Theory of Criminal Procedure, 15 SuP. CT. Econ. Rev. 61, 73 (2007), but, as discussed below, those interests also favor longer sentences.

87. See Richman, supra note 82 , at 966.

88. See infra note 112 and accompanying text.

89. See infra note 124 and accompanying text.

90. Easterbrook, supra note 77, at 295-96.

91. Landes, supra note 85 , at 63; accord Smith, supra note 85 , at 928 n. 123 .

92. If McGruff's understanding of deterrence theory is sophisticated, the longer the base sentence is, the longer a sentence reduction will be required to deter him. Economist-prosecutor McGruff would understand that each added year in a criminal sentence has a decreasing marginal deterrent effect on crime because criminals (like other people) discount harms that await them far into the future. See Easterbrook, supra note 77, at 295.

93. Scholars have generally so assumed. E.g., Stuntz, supra note 82 , at 46 n.159. In addition, one survey of federal prosecutors found a small but "growing" minority of so-called "deadwood" career prosecutors who "seek the easiest types of cases." Todd Lochner, Strategic Behavior and Prosecutorial Agenda Setting in United States Attorneys' Offices: The Role of U.S. Attorneys and Their Assistants, 23 Just. Sys. J. 271, 285-87 (2002). 
take them to trial and win an expected sentence longer than the one they will receive if they plead guilty. Because Sleepy seeks to avoid trial, she wants a high ratio between expected trial sentences and expected post-plea sentences--a high penalty for going to trial. ${ }^{94}$ Although Sleepy does not seek to increase the sentences of those defendants who plead guilty (indeed, she seeks to reduce them), she does want high sentences for those who go to trial. So, a sentence reduction based on her trial misconduct would count as a setback. ${ }^{95}$

\section{Career Advancement}

Now consider Hotshot and Moneybags, young assistant district attorneys whose sole objective is to advance their own career ambitions. Again, these are merely ideal types--but many commentators have suggested that career interests are important motivators for prosecutors. ${ }^{96}$ Hotshot hopes to climb the internal office ladder; Moneybags plans to cash in on his experience by moving to a private law firm in two or three years. ${ }^{97}$ Their motivations differ in some ways-Moneybags may be especially concerned with gaining particularly relevant trial experience or having positive interactions with the defense bar. ${ }^{98}$ But like Hotshot, Moneybags cares about impressing his superiors by successfully implementing the office's institutional agenda-Moneybags may not be seeking internal promotion, but he does need positive references and a general reputation as a successful prosecutor. ${ }^{99}$

Both Hotshot and Moneybags are likely to prefer longer sentences. Many offices actually require their line prosecutors to seek the highest available sentences. ${ }^{100}$ Junior prosecutors' job performance is often evaluated in part on

94. See Miller, supra note 71 , at 1258.

95. To be sure, some defendants no doubt enter plea agreements without much information about the specific prosecutor they face, which weakens Sleepy's incentive to pursue a reputation for winning high sentences at trial. Still, at least some defendants (or their counsel, more likely) would probably have such information, so Sleepy should have at least some incentive toward high sentences. Moreover, if Sleepy thought her reputation did not affect her ability to get pleas, she would not particularly care about winning either and thus would not have any incentive to commit deliberate misconduct in the first place (though her laziness might make her susceptible to negligence).

96. E.g., James Eisenstein, Counsel for the Untted States: U.S. Attorneys in the Polttical and LEGAL SYSTEMS 174 (1978); Dunahoe, supra note 17, at 49, 60; Lochner, supra note 93, at 277.

97. Much of the literature on prosecutors has focused on federal prosecutors and has assumed that most are transient like Moneybags. Lochner, supra note 93, at 273-74 (reviewing literature). This may no longer be accurate-Lochner's study found that Hotshot-like careerists have recently come to dominate U.S. Attorney's offices. See id. at 281-84. In any event, Hotshot and Moneybags are likely to have similar reasons to avoid sentence reductions.

98. See Richard T. Boylan \& Cheryl X. Long, Salaries, Plea Rates, and the Career Objectives of Federal Prosecutors, 48 J.L. \& Econ. 627, 627-28, 648 (2005) (finding that high private-sector salaries encourage prosecutors to try high-profile cases to impress potential employers).

99. See Fisher, supra note 46, at 206; Richard Posner, An Economic Approach to the Law of Evidence, 51 STAN. L. REv. 1477, 1505 (1999) ("Future employers will evaluate a prosecutor by his success in litigation ....").

100. See, e.g., Memorandum from John Ashcroft, Attorney Gen., U.S. Dep't of Justice, to All Fed. Prosecutors (Sept. 22, 2003), available at http://www.crimelynx.com/ashchargememo.html (requiring prosecutors "to Pursue the Most Serious, Readily Provable Offense," measuring seriousness by length 
the basis of the sentences they obtain. ${ }^{101}$ Conviction rate is also important, of course, ${ }^{102}$ and reversal or mistrial would presumably be a bigger "loss" than a reduced sentence-so to be as effective in deterring Hotshot and Moneybags from misconduct, sentence reduction would have to be perceived as more likely. And efficient docket management is also generally an important measurement of performance-so Hotshot and Moneybags, like Sleepy, have an interest in encouraging pleas by maintaining a high trial penalty.

Even more than they fear the sentence reduction itself, Hotshot and Moneybags are likely to fear the professional embarrassment of being found by a court to have committed wrongdoing. ${ }^{103}$ Perhaps they might not experience much professional harm as a result of a lenient trial judge simply going easy on a defendant - their superiors might not even notice, unless it was an especially high-visibility case, and might not hold it against Hotshot or Moneybags if they did notice. But what if a trial court justified its sentence, or an appeals court ordered a reduction in the trial sentence, on the express basis of a prosecutor's violation of the defendant's rights? Even assuming the court named no names, there is little doubt that the prosecutor's superiors would find out. ${ }^{104}$

So if having the option of an intermediate remedy makes the court more willing to make an embarrassing finding of prosecutorial wrongdoing, it might deter Hotshot and Moneybags even assuming they didn't care very much about sentence length per se. In theory, this reputational sanction might have some deterrent effect even absent any remedy - that is, prosecutors should get embar-

of sentence, and stating that the "use of statutory enhancements is strongly encouraged"); Memorandum from James B. Comey, Deputy Attorney Gen., U.S. Dep't of Justice, to All Fed. Prosecutors (Jan. 28, 2005), available at http://sentencing.typepad.com/sentencing_law_and_policy/files/dag_jan_ 28_comey_memo_on_booker.pdf (requiring federal prosecutors to oppose every below-Guidelines sentence); Richard Thornburgh, United States Department of Justice Plea Policy for Federal Prosecutors (1989), reprinted in 6 FED. SENT'G REP. 347 (1994) (similar); Miller, supra note 71, at 1255 (observing that this "basic policy" dates back to 1980). These policies contain loopholes that permit some discretion, see $i d$. at 1257 , but still clearly reflect a general institutional preference for high sentences.

101. See Fisher, supra note 46, at 206 (noting that prosecutors' "competence ... tends to be measured in terms of 'wins,' i.e., 'heavy' convictions and sentences"); Meares, supra note 17, at 885 (noting that "effectiveness can be measured ... by a combination of the prosecutor's conviction rate and the severity of sentences"); Nat'l Dist. Attorneys Ass'n, Performance Measures for Prosecutors: Findings from the Application of Performance Measures in Two Prosecutors' Offices 14 (2007), http://www.ndaa.org/pdf/performance_measures_findings_07.pdf (listing "sentence length" among eight "core performance measures").

102. See, e.g., Robert L. Rabin, Agency Criminal Referrals in the Federal System: An Empirical Study of Prosecutorial Discretion, 24 STAN. L. REv, 1036, 1045 (1972); Richman, supra note 82, at 968.

103. See Fisher, supra note 46, at 215-16 (noting that reputation for overzealousness can harm prosecutors' careers); Meares, supra note 17 , at $918 \& \mathrm{n} .52$ (noting that prosecutors care greatly about impressing colleagues and seek to "avoid embarrassing losses"); Jerome H. Skolnick, Social Control in the Adversary System, 11 J. CONFLICT RESOL. 52, 57-58 (1967) (stating that prosecutors seek "a reputation for utter credibility").

104. See Alshuler, supra note 17, at 647 (noting that "[w]hen the behavior of an assistant district attorney leads to a reversal, his superiors know about it"). Even Sleepys might be motivated to avoid this embarrassment because judicially punished misconduct might provide the rare "good cause" needed to fire under-performing civil servants. See Lochner, supra note 93, at 283-84. 
rassed when misconduct is identified on appeal but deemed harmless. But Hotshot and Moneybags may well assume that their bosses will not put much stock in such toothless reprimands. Indeed, many scholars and courts have observed that prosecutors pay limited attention to judicial findings of misconduct until they are combined with some effect on the "bottom line." ${ }^{105}$ Likewise, the main current trial-level remedy for misconduct-judicial admonishment and a curative instruction-is unlikely even to be noticed by their bosses, who presumably neither sit in on their trials nor carefully review each trial transcript. ${ }^{106}$ An explicit sentence reduction due to misconduct, however, would likely make supervisors take notice.

\section{Winning}

A fifth hypothetical prosecutor, Champ, is hyper-competitive-he thrives on the adversarial process, and his overriding incentive is simply to win. Although he represents an extreme, competitiveness is a trait he shares with many prosecutors. ${ }^{107}$ Champ pays a lot of attention to his conviction rate. But he doesn': just want to rack up easy convictions-he wants high-stakes wins and thus aims for severe sentences. ${ }^{108} \mathrm{He}$ wants to win at the sentencing stage, not just at the trial stage-in a system dominated by pleas, sentence length is the main way Champ can quantify his success. Because he also wants to induce the most favorable pleas, he too needs to maintain a steep trial penalty, requiring high sentences after trials. And he wants to win on appeal, too, which means preserving the trial result. ${ }^{109}$ A sentence reduction based on his misconduct would thus amount to a loss.

105. Fisher, supra note 46, at 213; accord United States v. Pallais, 921 F.2d 684, 691-92 (7th Cir. 1990); Allen, supra note 24 , at 334 . One former federal prosecutor told me that the actual inclusion of the word "misconduct" in an opinion would embarrass many prosecutors even absent a concrete remedy and that courts vary in their willingness to use this loaded term. Email from Mary Fan, Assistant Professor of Law, Washington College of Law, to author (Aug. 18, 2008) (on file with author). To avoid remedial deterrence, my proposal would not require courts to use that term; sentence reduction would be triggered by the finding of a rights violation caused by the prosecutor's actions, not by any "magic word." In addition, although most prosecutors might well be ashamed by a misconduct finding standing alone, the "bad actors" who commit most misconduct may be likelier to disregard such findings absent some remedy. Misconduct "is frequently committed by repeat prosecutorial offenders," Dunahoe, supra note 17 , at 68 , suggesting that some prosecutors are not significantly discouraged by a first finding of misconduct, much less removed from their jobs as a result.

106. See Dunahoe, supra note 17, at 63 (noting loose day-to-day supervision of line prosecutors).

107. See Fisher, supra note 46, at 198 (discussing “conviction psychology"); Meares, supra note 17, at 918 (describing the "desire to win" as "a primary characteristic of existing prosecutorial culture"); Richman, supra note 82, at 967-68.

108. See Fisher, supra note 46, at 206, 208 (arguing that the adversary system drives prosecutors toward "maximizing convictions and punishments"); Posner, supra note 99, at 1505 (arguing that "the desire to win, weighted by the stakes in the case (roughly, the sentence if the defendant is convicted), is the most important argument in the prosecutorial utility function").

109. Even if Champ turned over the appeal to a different prosecutor, loss on appeal would hurt his "bottom line." See Meares, supra note 17, at 900. 


\section{Political Gain}

What about Chief, the elected district attorney? ${ }^{110}$ Her motives, let's hypothesize, are purely political-she responds to votes. ${ }^{111}$ Chief will want to reduce crime because voters pay great attention to crime rates, so she will share McGruff's incentives. ${ }^{112}$ Beyond the actual crime rates, Chief also wants to appear tough on crime and successful against criminals. That means pushing for tough sentences, which the public overwhelmingly supports. ${ }^{113}$ And it means that (like Champ) she cares about the bottom line-she wants her office to win, ${ }^{114}$ which includes winning tough sentences. ${ }^{115}$ All of these incentives will be especially magnified in the highest-profile cases, but they will be present to some degree in all cases.

On the other hand, Chief also doesn't want to be perceived as abusing her power or letting her line prosecutors do so. So she is likely to be embarrassed by a judicial opinion reducing a sentence because of her misconduct or that of her subordinates. ${ }^{116}$ Even if the opinion does not name the individual prosecutor involved, it makes the office as a whole look bad. And if the public is distressed by the reduced sentence, it may hold her to blame.

\section{Justice}

Finally, let's imagine a different sort of prosecutor, Angel. Angel's sole motivation is the one set forth for all prosecutors by the Supreme Court: to see "that justice shall be done." 117 Angel simply seeks fair punishments for crime. She is of course unlikely to commit deliberate misconduct to begin with, so her incentives may be less important, but let's assume that she is at least capable of

110. See Sanford C. Gordon \& Gregory A. Huber, Citizen Oversight and the Electoral Incentives of Criminal Prosecutors, 46 AM. J. PoL. ScI. 334, 335 (2002) (noting that over $95 \%$ of chief prosecutors at the state and local level are elected).

111. E.g., James Vorenberg, Decent Restraint of Prosecutorial Power, 94 Harv. L. Rev. 1521, 1558 (1981).

112. See Daniel C. Richman \& William J. Stuntz, Al Capone's Revenge: An Essay on the Political Economy of Pretextual Prosecution, 105 Colum. L. REv. 583, 602-03 (2005) (arguing that DAs are "fixated" on crime rate reports); Thompson, supra note 86, at 331.

113. See, e.g., Talbot "Sandy" D'Alemberte, A Critique of Roscoe Pound's Popular Dissatisfaction with the Administration of Justice: The Missing Discussion of Criminal Law, 48 S. TEx. L. Rev. 969, 971-72 (2007) (citing the "political reward for . . . long sentences"); Gordon \& Huber, supra note 110, at $335 \mathrm{n} .1$ (finding in survey that $77 \%$ wanted harsher sentences). Even unelected prosecutors may face political pressure to increase sentences. See Suzanne Weaver, Decision to Prosecute: Organization AND Public Policy IN tHe ANTrtrust Division 144-45 (1977) (discussing congressional oversight of DOJ antitrust prosecution).

114. See Fisher, supra note 46, at 205; Gordon \& Huber, supra note 110, at 350 (arguing that "voters will always reward prosecutors for obtaining convictions"); Richman, supra note 82, at 967.

115. See Gordon \& Huber, supra note 110, at 337 (noting that district attorney candidates emphasize sentences in addition to conviction rates).

116. Id. at $335 \& \mathrm{n} .2$ (noting that misconduct sometimes produces "well-publicized scandals"); see also Fisher, supra note 46, at 207 ("Unless it results in reversal of the conviction, or public scandal, the prosecutor's choice to act 'overzealously' can be cost-free." (emphasis added)).

117. Berger v. United States, 295 U.S. 78, 88 (1938); see Fisher, supra note 46, at 216 (citing professional standards). 
negligence, or can be tempted into a fall from grace, so to speak, if it serves what she sees as a just end.

Angel does not aim for severe punishments per se-she may think leniency is appropriate in some circumstances. But she nonetheless would want to avoid sentence reduction on the basis of misconduct. After all, she has extremely broad discretion over charging ${ }^{118}$ and plea bargaining, ${ }^{119}$ and she can also make a sentence recommendation that judges will rarely exceed. ${ }^{120}$ So Angel has plenty of tools available to achieve a lower sentence for a particular defendant if that is what justice requires. Once she has selected the charges, won at trial or accepted a plea, and recommended a sentence, the defendant will usually receive a sentence no higher than Angel thought just. A subsequent sentence reduction on the basis of misconduct will thus seem to her to subvert justice. Moreover, as an ethically conscious member of the profession, she may "find a judicial rebuke especially stinging." 121

None of these archetypes, of course, perfectly describes real-world prosecutors. Different prosecutors have varying incentives, ${ }^{122}$ and each has multiple incentives. ${ }^{123}$ Moreover, their preferences are not fixed-they are influenced by office culture ${ }^{124}$ and may evolve over time. ${ }^{125}$ Yet the hypotheticals above suggest that despite this complexity, virtually all prosecutors will be dismayed by a sentence reduction based on misconduct. In this respect, their motivations are mutually reinforcing.

\section{EVIDENCE ABOUT REAL PROSECUTORS' PREFERENCES}

Most scholars have assumed that prosecutors prefer higher sentences, ${ }^{126}$ and the existing empirical evidence supports that assumption. First, prosecutors' offices tend to support tough sentencing laws. ${ }^{127}$ Some scholars suggest that this

118. Even if office policy nominally constrains her charging, in practice she probably has some discretion. See Miller, supra note 71, at 1257; Richman, supra note 16, at 2068-69.

119. E.g., Bowman \& Heise, supra note 71, at 1119-24.

120. Ronald F. Wright, Sentencing Commissions as Provocateurs of Prosecutorial Self-Regulation, 105 Colum. L. Rev. 1010, 1011 n.3 (2005); see also Bowman \& Heise, supra note 71, at 1116-18 (noting prosecutors' discretion to seek "substantial assistance" departures).

121. Alschuler, supra note 17, at 647.

122. See Richman, supra note 16, at 2056, 2074; Kate Stith, The Arc of the Pendulum: Judges, Prosecutors, and the Exercise of Discretion 17 (2008), available at http://papers.ssrn.com/sol3/ papers.cfm?abstract_id=1099064 (noting that Assistant U.S. Attorneys' charging and plea bargaining practices vary widely both between and within districts).

123. E.g., Glaeser et al., supra note 86, at 260-61, 268.

124. See Meares, supra note 17, at 918; Leonard R. Mellon et al., The Prosecutor Constrained by His Environment: A New Look at Discretionary Justice in the United States, 72 J. CRIM. L. \& CRIMINOLOGY 52, 79 (1981).

125. See, e.g., Fisher, supra note 46 , at $206-07$.

126. See, e.g., Smith, supra note 85 , at $896,928$.

127. See, e.g., Troy Anderson, D.A., Sheriff Says Inmates Will Soon Serve Longer Terms, DalLY NEws of L.A., Nov. 9, 2006, at N6; Bob Bernick Jr., No More 5-to-Life Sentences for Killers in Utah?, Deseret Morning News (Utah), Sept. 25, 2005; Matthew Franck, Prosecutors Criticize Child-Sex Bill, St. Louis Post-Dispatch, Apr. 27, 2006, at D4; Andy Furillo, Revisions to Three-Strikes Law Sought, 
is because such laws increase prosecutors' plea-bargaining leverage, not because of a preference for harshness per se. ${ }^{128}$ Even if this is true, however, the result is the same: to encourage pleas, prosecutors need post-trial sentences to be harsh ${ }^{129}$ and thus would want to avoid sentence reduction as a consequence of misconduct during the pretrial or trial process. Second, when choosing among multiple possible theories of criminal liability, prosecutors usually pursue the charges carrying the highest sentence. ${ }^{.130}$ As noted above, many offices require prosecutors to do so. ${ }^{131}$ Third, district attorney candidates sometimes campaign on a platform of increased sentence severity. ${ }^{132}$ Finally, the culture of prosecutors' offices often creates 'pressures ... to renounce quasi-judicial values in favor of pursuing penal severity."133

There may well be exceptions; not every prosecutor pushes for the strongest sentence in every circumstance, just as not every prosecutor seeks convictions at all costs. ${ }^{134}$ For instance, in federal drug cases, given the particularly harsh applicable sentencing laws, prosecutorial leniency may be disproportionately common. ${ }^{135}$ But as a general rule, most prosecutors, even the Angels, would prefer to avoid sentence reductions. Moreover, the subset of prosecutors who are the most likely to commit misconduct may experience the most harm from a sentence reduction. Many scholars have suggested that both a tendency to commit misconduct and an especially strong preference for "penal severity over other potential goals" are symptoms of the same underlying characteristic, namely "overzealousness." 136

Although prosecutors are likely to care less about sentences than about convictions, ${ }^{137}$ sentence reduction might sometimes amount to a more severe penalty than appellate reversal or mistrial because either reversal or mistrial could ultimately permit conviction, resulting in a non-reduced sentence, after

EAST CounTY TIMEs (Cal.), Jan. 18, 2006, at A11; Stacey Range, Embezzlers May Face Tougher Penalties Under Mich. Proposal, Lansing ST. J. (Mich.), Sept. 25, 2006, at 1A; Jonathan Saltzman, Push Is On to Keep Sex Criminals Locked Up, Boston Globe, Oct. 25, 2005, at A1.

128. See, e.g., Miller, supra note 71, at 1215.

129. See id. at 1253 (arguing that prosecutors like the federal sentencing guidelines because they have greatly increased "prosecutorial control . . . over the plea/trial differential").

130. Smith, supra note 85 , at $922-25$.

131. See supra note 100 and accompanying text.

132. Gordon \& Huber, supra note 110 , at 337.

133. Fisher, supra note 46, at 254-55; see supra notes 107,124 and accompanying text.

134. See Fisher, supra note 46, at 245-46 \& n.197; Alissa Pollitz Worden, Policymaking By Prosecutors: The Use of Discretion in Regulating Plea Bargaining, 73 JUdiCATURE 335, 335 (1990).

135. Bowman \& Heise, supra note 71, at 1049-50, 1131-33.

136. Fisher, supra note 46, at 198-200 \& nn.2-8, 15-16 (collecting sources); see Dunahoe, supra note 17 , at 68 (noting that "deliberate, flagrant, pervasive, and prejudicial prosecutorial abuse ... is frequently committed by repeat prosecutorial offenders").

137. Conviction rates are probably the most basic measurement of prosecutorial performance. See, e.g., Hylton \& Khanna, supra note 86, at 85 (noting that prosecutors "are rewarded when conviction rates are high"); Thompson, supra note 86 , at 331. 
retrial. ${ }^{138}$ In any case, convictions are not everything to prosecutors. For instance, prosecutors often charge more serious offenses carrying higher sentences even when doing so significantly increases the chance of acquittal. ${ }^{139}$

The trick to improving deterrence vis-à-vis the all-or-nothing system-and it may be a challenging one-would be calibrating the sentence reduction's magnitude. An appropriate reduction should be significant enough for prosecutors to fear it, but not so significant that courts will treat it as the functional equivalent of a reversal or dismissal (and thus be unwilling to grant it). This task might require some trial and error. ${ }^{140}$ Leaving the magnitude of the reduction up to the court would presumably take care of the second concern, but there is some risk that such flexibility would result in reductions so small as to undermine deterrence. However, even small reductions might achieve effective deterrence if prosecutors are substantially motivated by fear of professional embarrassment-any reduction would be enough to call attention to the underlying misconduct. In any event, if there is truth to the apparent scholarly consensus that the current remedies for prosecutorial misconduct are largely devoid of deterrent effect, it is time to take a chance on an alternative.

\section{Sentence Reduction as a Corrective and Expressive Remedy}

Constitutional remedies are not solely designed to deter misconduct, of course. Many are designed to compensate victims of rights violations or to express condemnation of wrongdoing. I discuss those corrective and expressive purposes in sections $\mathrm{A}$ and $\mathrm{B}$, respectively. In sections $\mathrm{C}$ and $\mathrm{D}, \mathrm{I}$ argue that current remedies do not serve these purposes well and that sentence reduction would serve them better-and not just because it is much likelier to be granted: Sentence reduction can be tailored in magnitude, offering more precision in compensating the defendant and making it less likely that the expressive message will be clouded by the perception of a windfall. Finally, section $E$ argues that using sentence reduction to serve corrective and expressive purposes will not interfere unduly with traditional sentencing objectives.

\section{A. CRIMINAL PROCEDURE REMEDIES AS CORRECTIVE JUSTICE}

At least since Marbury v. Madison, U.S. constitutional cases have often invoked the maxim that there is no right without a remedy. ${ }^{141}$ Constitutional remedies have traditionally sought to repair the impact of the violation to "the

138. See Cicchini, supra note 17, at 336 (arguing that retrials greatly reduce the deterrent effect of reversal). Where permitted, reversals may result in plea bargaining. See Posner, supra note 40 , at 644 . Sentence reduction could be worse than reversal for the prosecutor if its magnitude exceeds the concessions needed to get the defendant to take a plea.

139. See Richman \& Stuntz, supra note 112, at 608.

140. This problem is not unique to sentence reduction; similar uncertainty plagues all deterrent remedies in constitutional law. Meltzer, supra note 57, at 290-91; see also Dan M. Kahan; The Secret Ambition of Deterrence, 113 HARv. L. Rev. 413, 427-28 (1999).

141. Marbury v. Madison, 5 U.S. (1 Cranch) 137, 163 (1803). 
greatest possible degree"- that is, to make the defendant whole. ${ }^{142}$ This idea, which is a form of "corrective justice," has also played a central role in private law. Although modern scholarship emphasizes efficiency concerns, ${ }^{143}$ private law remedies traditionally seek to restore the plaintiff to her "rightful position." 144 It is deeply rooted in the English common law ${ }^{145}$ and in legal systems throughout the world. ${ }^{146}$ This principle is not without exceptions-right-remedy gaps in practice have always been common as a result of immunities and other barriers to relief. ${ }^{147}$ Moreover, constitutional remedies, like private law remedies, serve other, non-corrective purposes as well and are shaped by the balancing of competing interests. ${ }^{148}$ Still, corrective justice remains important in shaping constitutional remedies and as a norm of our legal culture. ${ }^{149}$

In criminal cases involving defensive invocation of procedural rights, courts tend to be less explicit in invoking the "make-whole" principle, sometimes entirely eschewing corrective rationales for remedies. ${ }^{150}$ Nonetheless, corrective justice is one of the primary purposes of many criminal procedure remedies. The harmless error rule is grounded in this principle: if there is no harm of wrongful conviction to be corrected, there is no justification for a remedy. When the Supreme Court has declined to apply harmless error review, it has sometimes been on the ground that some non-conviction-related harm needed to be redressed. For instance, in Speedy Trial Clause cases, the Supreme Court has held that dismissal is necessary to compensate the defendant for the emotional harm suffered due to the delay in trial. ${ }^{151}$

Moreover, criminal procedure scholars often invoke corrective justice prin-

142. Davis v. Bd. of Sch. Comm'rs of Mobile County, 402 U.S. 33, 37 (1979); see Abram Chayes, The Role of the Judge in Public Law Litigation, 89 HARV. L. REv. 1281, 1282-83 (1976); Meltzer, supra note 57 , at 249 .

143. E.g., Jules Coleman, The Costs of the Costs of Accidents, 64 MD. L. REv. 337, 348-54 (2005) (describing and critiquing this shift away from corrective justice).

144. E.g., Douglas Laycock, Modern American Remedies 16 (3d ed. 2002).

145. See 3 William Blackstone, Commentaries *23; Albert Dicey, An Introduction to the Study of tHE LAW OF THE Constitution 199 (10th ed. 1959).

146. See Starr, supra note 6, at 698-705.

147. See, e.g., Richard H. Fallon \& Daniel J. Meltzer, New Law, Non-Retroactivity, and Constitutional Remedies, 104 HARV. L. REv. 1731, 1765, 1778, 1784 (1991).

148. For instance, remedies in institutional reform litigation involve complicated policy choices. See Chayes, supra note 142, at 1296-1302; Owen Fiss, The Supreme Court, 1978 Term-Foreword: The Forms of Justice, 93 HaRv. L. Rev. 1, 47-48 (1979); see also David I. LeVINE ET AL., ReMEdies: PuBlic AND PRIVATE 9-10, 12 (2006) (arguing that both private and public law remedies involve such discretionary choices); Douglas Laycock, The Triumph of Equity, LAw \& ConTEMP. ProBs., Summer 1993, at 53, 71-73 (arguing that discretion and compromise pervade common law remedial decisionmaking).

149. See Fallon \& Meltzer, supra note 147, at 1786 (observing that notwithstanding right-remedy. gaps, "[e]ffective remedies have always been available for most violations of legal rights").

150. For instance, the Supreme Court has usually sought to justify the Fourth Amendment exclusionary rule in deterrence terms alone. See United States v. Leon, 468 U.S. 897, 906 (1984); United States v. Calandra, 414 U.S. 338, 347 (1974).

151. Strunk v. United States, 412 U.S. 434, 439 (1973). For a discussion of this holding, see infra section V.A. 
ciples when criticizing current doctrine. For instance, defenders of the exclusionary rule often criticize the Supreme Court's reliance on deterrence to justify it, arguing that courts can too easily chip away at the rule by claiming that a particular application has little marginal deterrent value. ${ }^{152}$ They contend that the rule should instead be justified on corrective grounds: the injury done by the unlawful search must be corrected by refusal to admit the resulting evidence. ${ }^{153}$ As the case studies in Part V will illustrate, inconsistency with the corrective principle-lack of fit between wrong and remedy-likewise underlies many criticisms of current remedies for prosecutorial misconduct.

\section{B. EXPRESSIVE THEORIES OF REMEDIES}

Scholars often argue that remedies for prosecutorial misconduct should "send a message" to the prosecutor. ${ }^{154}$ These arguments go beyond deterrence-the desired message is not just about the consequences misconduct will trigger, but also about its wrongfulness. These arguments are expressive in nature.

Expressive theories of law are concerned with using the law to counter "expressive harms." They are premised on the idea that wrongful conduct can do harm because of what it means-often because it conveys a lack of respect for another individual's dignity or humanity. ${ }^{155}$ As Elizabeth Anderson and Richard Pildes point out, for instance, the harm you experience when your neighbor knowingly dumps trash on your lawn is quite different from the harm you experience when the wind blows the same trash there. ${ }^{156}$ The burden of picking it up is the same and relatively minor, but in the former case, it is greatly magnified by the feeling of having been treated with contempt.

Government actions can likewise inflict expressive harms-indeed, "[o]ften it seems to matter more to individuals what the government says than what other private actors say." 157 Such expressive harms go beyond the particular individuals directly affected because of "the way in which they undermine collective understandings." ${ }^{158}$ When government actors disregard individual rights, they

152. Meltzer, supra note 57 , at 268-69 (citing such critics but disagreeing with them).

153. Id.

154. See, e.g., Russell D. Covey, The Unbearable Lightness of Batson: Mixed Motives and Discrimination in Jury Selection, 66 MD. L. REv. 279, 318-19 (2007); Joy, supra note 17, at 428-29; Robert P. Mosteller, Exculpatory Evidence, Ethics, and the Road to the Disbarment of Mike Nifong: The Critical Importance of Full Open-File Discovery, 15 GEO. MASON L. REv. 257, 317-18 (2008); Williams, supra note 62 , at 1200 .

155. E.g., Jean Hampton, Correcting Harms Versus Righting Wrongs: The Goal of Retribution, 39 UCLA L. REv. 1659, 1666 (1992).

156. Elizabeth S. Anderson \& Richard H. Pildes, Expressive Theories of Law, 148 U. PA. L. REV. 1503, 1528 (2000).

157. Richard H. McAdams, An Attitudinal Theory of Expressive Law, 79 OR. L. REv. 339, 381 (2000); see also Richard H. Pildes, Why Rights Are Not Trumps: Social Meanings, Expressive Harms, and Constitutionalism, 27 J. LEGAL STUD. 725, 726 (1998).

158. Pildes, supra note 157 , at 755. 
do expressive harm by sending "demeaning messages about human worth." 159 They do so even if the misconduct is meant to be kept secret, for expressive harms are not confined to acts that are deliberately communicative-just as your trash-throwing neighbor's rudeness would unmistakably express contempt toward you even if she didn't know you were watching. ${ }^{160}$

One objective of legal remedies is to combat these kinds of expressive harms, to respond to a wrongful message with a better message. ${ }^{161}$ As Anderson and Pildes put it, " $[E]$ xpressive legal remedies' matter because they express recognition of injury and reaffirmation of the underlying normative principles for how the relevant relationships are to be constituted." ${ }^{162}$ For instance, Lawrence Friedman argues that the Fourth Amendment exclusionary rule "serves to vindicate publicly the search victim's privacy interest: it represents the means by which the community, speaking through the judiciary, answers the government's incorrect valuation of privacy."163

Beyond the "intrinsic" value of expressing such morally sound judgments, ${ }^{164}$ expressive theories are often framed in consequentialist terms. When the law expresses morally sound judgments, it encourages people to act consistently with those judgments. ${ }^{165}$ Such arguments share with deterrence arguments a primary concern with shaping behavior - but they seek to do so not just by making people fear specific penalties, but by shaping social norms. ${ }^{166}$

The corrective and expressive justifications for criminal procedure remedies are closely intertwined. An appropriate expressive remedy for prosecutorial misconduct would seek to "make the defendant whole" in an important sense-to restore full respect for his humanity and his rights as a full member of the community. In a culture that gives pride of place to the Marbury principle, the most effective expressive remedy will often be a corrective one because culturally we understand such remedies to "restore" victims of wrongdoing to their "rightful positions." ${ }^{167}$ Likewise, arguments for corrective justice often sound in expressive terms-for instance, Margaret Jane Radin argues that "corrective

159. Andrew E. Taslitz, The Expressive Fourth Amendment: Rethinking the Good Faith Exception to the Exclusionary Rule, 76 Miss. L.J. 483, 564 (2006); see Cicchini, supra note 17, at 343-44.

160. See Anderson \& Pildes, supra note 156, at 1565-67.

161. E.g., Brent T. White, Say You're Sorry, 91 CoRNELL L. REv. 1261, 1278 (2006)

162. Anderson \& Pildes, supra note 156, at 1529; see, e.g., Baher Azmy, Unshackling the Thirteenth Amendment, 71 Fordham L. Rev. 981,1048 (2002).

163. Lawrence Friedman, Reactive and Incompletely Theorized State Constitutional DecisionMaking, 77 Miss. L.J. 265, 286 (2007).

164. Cass R. Sunstein, On the Expressive Function of Law, 144 U. PA. L. REv. 2021, 2026-27 (1996) (discussing arguments of Bernard Williams).

165. McAdams, supra note 157, at 340; Pildes, supra note 157, at 755; Paul H. Robinson \& John M. Darley, The Utility of Desert, 91 Nw. U. L. Rev. 453, 454-57 (1997); Sunstein, supra note 164, at 2025-27 (distinguishing these two approaches to expressive law).

166. See McAdams; supra note 157, 371-73 (arguing that economists should make "the expressive consequences of law a standard component of their models").

167. See Friedman, supra note 163, at 286 (arguing that restoring "the status quo ante ... recognizes the expressive injury and reaffirms" the proper relationship between the parties). 
justice restores moral balance between the parties" and "show[s] the victim that her rights are taken seriously." 168

Expressive remedies are thus usually ineffective if they are merely expressive, for instance declaratory relief (as a response to past harm) or simple judicial recognition of wrongdoing. Remedies that diverge from the corrective principle may sometimes still be expressively valuable. As Anderson and Pildes point out, for instance, landowners subject to state takings often prefer "token compensation" to no compensation, while victims of constitutional wrongs often take even nominal damages seriously. ${ }^{169}$ But usually, at least some concrete relief mitigating the effects of the rights violation is necessary for the expressive message to be taken seriously. Otherwise, "the judicial declaration of the expressive harm and reaffirmation of the proper relationship between individuals and the government would ring hollow.",170

In addition to recognizing the dignity and humanity of the wronged party, legal remedies can also serve a second expressive purpose: condemning wrongdoing. Expressive theories of law have often focused on the power of the law to marshal social opprobrium. In an influential essay, Joel Feinberg argued that criminal punishment should express "attitudes of resentment and indignation." 171 Likewise, Paul Robinson and John Darley have argued that social science

research consistently finds that fear of social disapproval and moral commitment to the law both inhibit the commission of illegal activity.

$\cdots$

The prosecution of a deviant brands the deviant as a criminal and casts a bright light on the exact location of a boundary that previously might have been obscure to the community. ${ }^{172}$

Expressions of condemnation thus speak to a broader audience than the parties to the case, and they also can induce appropriate shame in the wrongdoer herself. ${ }^{173}$

168. Margaret Jane Radin, Compensation and Commensurability, 43 DuKe L.J. 56, 60-61 (1993) (noting, however, that there is "no canonical conception of corrective justice").

169. Anderson \& Pildes, supra note 156, at 1529; see also Carey v. Piphus, 435 U.S. 247, 266 (1978) (holding that through nominal damages awards, "the law recognizes the importance" of those rights to society). But see White, supra note 161, at 1278-79 (arguing that limiting relief to nominal damages suggests "that the municipality's actions weren't all that serious").

170. Friedman, supra note 163, at 289; see also Hampton, supra note 155, at 1686-87.

171. Joel Feinberg, The Expressive Function of Punishment, in 4 PhLOSOPHY OF LaW: CRIMEs AND Punishments 87, 90 (Jules L. Coleman ed., 1994).

172. Robinson \& Darley, supra note 165 , at 470,472 ; see also Carol S. Steiker, Punishment and Procedure: Punishment Theory and the Criminal-Civil Divide, 85 GEo. L.J. 775, 800-06 (1997).

173. See Steiker, supra note 172, at 807 (discussing how punishment "reach[es] inside the self"). 
Scholars advancing condemnation-centered expressive theories have mainly focused on criminal punishment. But other legal remedies can also be understood to serve the purpose of condemnation. Indeed, remedies awarded to criminal defendants are often described as "sanctions" for prosecutorial misconduct. ${ }^{174}$ To be sure, they do not "punish" the individual prosecutor in the traditional sense of the word-the defendant, not the prosecutor, is the direct object of the remedy. But they often share something important in common with punishment: the intent to condemn or blame. ${ }^{175}$ And the judicial condemnation accompanying such remedies may publicly embarrass the prosecutor in a way that affects her more than the remedies alone would. ${ }^{176}$

The two expressive purposes I have discussed here are distinct, although intertwined. The defendant-centered expressive purpose is essentially corrective-it focuses on making the defendant whole for expressive harms. The prosecutor-centered purpose is essentially retributive. ${ }^{177}$ The remedial implications will sometimes differ, particularly when the prosecutor's wrongdoing was egregious but the defendant suffered only minor expressive harm. This point is further discussed in the next two sections.

\section{THE WINDFALL PROBLEM}

These corrective and expressive objectives risk being undermined by excessive remedies (windfalls), not just by insufficient ones. Strong remedies like reversal, mistrial, or dismissal may thus sometimes be counterproductive responses to prosecutorial misconduct-and not only because courts, as discussed in Part I, are usually unwilling to grant such windfalls.

The harm of windfalls is easy to understand in corrective terms: they overcorrect and thus restore the defendant not to his rightful position, but to a superior position. If restoration of the status quo ante is the moral ideal, overcorrection is as problematic as undercorrection. ${ }^{178}$ But the problem from an expressive perspective is less obvious: if we want to condemn conduct, why is a more vociferous condemnation not always better?

The answer lies in the centrality of desert to expressive theories of law. As scholars have recognized, the expressive value of law turns on its perceived moral legitimacy, without which it cannot effectively shape social norms. ${ }^{179}$ One important factor in determining legitimacy is that the law does not diverge too greatly from cultural intuitions concerning fairness. These intuitions include

174. E.g., United States v. Mendoza, 522 F.3d 482, 495 (5th Cir. 2008); United States v. Helmandollar, 852 F.2d 498, 502 n.3 (9th Cir. 1988); United States v. Modica, 663 F.2d 1173, 1184 (2d Cir. 1981).

175. See Steiker, supra note 172, at 803-04 (describing "blaming" as the core purpose of punishment).

176. See supra section III.B.

177. See Hampton, supra note 155, at 1663 (explaining that corrective justice is concerned with harms while retributive justice is concerned with "wrongful actions").

178. E.g., Tracy A. Thomas, Proportionality and the Supreme Court's Jurisprudence of Remedies, 59 HASTINGS L.J. 73, 83 (2007).

179. E.g., Robinson \& Darley, supra note 165, at 457. 
the notion that remedies and punishments should be apportioned, at least roughly, only as deserved.

Windfall remedies threaten this desert principle in two ways. First, because they go beyond the requirements of corrective justice, they may be perceived as giving the defendant more than he deserves. Rather than sending a positive message restoring respect for the defendant's dignity and humanity, the remedy may just provoke resentment. ${ }^{180}$

Second, proportionality and desert also matter to the effectiveness of condemnation as well. If remedies are perceived as disproportionate to the wrongdoing that they are intended to condemn, they may be seen as retributively unjustified. This is especially true when similar prosecutorial misconduct usually meets with no remedy at all. If the unlucky few prosecutors are not perceived as "deserving" the loss inflicted by those remedies, the desired stigma may be lost. As Stephen Schulhofer argues with respect to disparately distributed criminal punishment:

[D]esert is a vital component of an efficient sanctioning system because desert is essential to the stigmatizing effects of punishment....

... [R]andomly punishing only one in ten robbers would seriously undermine that requirement.... [T] to the extent that a severe punishment brands the tenth robber not as an extraordinarily bad person but only as an extraordinarily unlucky one. ${ }^{181}$

Robinson and Darley have likewise argued that punishment cannot effectively shape social norms if it is seen as arbitrary or undeserved. Because "the criminal law's most important real-world effect may be its ability" to shape social norms, excessive punishment may have a net negative effect on compliance with law-the marginal deterrent benefit "is outweighed by the additional cost" to the "law's moral credibility." 182 Although these arguments focus on criminal punishment, their logic also applies to the use of windfall remedies to condemn prosecutors. ${ }^{183}$ The effectiveness of those remedies' message will likely be undermined by the perception that the condemnation goes beyond what is deserved.

All-or-nothing remedial schemes for misconduct thus often pose unsavory choices. Granting the remedy produces a windfall that is excessive from a corrective perspective and unsatisfactory from an expressive perspective. But denying a remedy fails to correct the harm that the defendant did suffer and sends the equally unacceptable message that the court tolerates the misconduct.

180. See supra section III.B.5.

181. Stephen J. Schulhofer, Criminal Justice Discretion as a Regulatory System, 17 J. LEGAL STUD. 43, 68 (1988).

182. Robinson \& Darley, supra note 165 , at $457-58$.

183. Cf. White, supra note 161 , at 1279-80 (arguing that perceived excessive size of punitive damage verdicts undermines their expressive message). 


\section{SENTENCE REDUCTION AS A TAILORED REMEDY}

To resolve these all-or-nothing dilemmas, it may be necessary to find an alternative that is less of a blunt instrument. Sentence reduction is one possibility. Because a sentence reduction could be of any magnitude-from a nominal reduction to the entire length of the base sentence-it can be tailored to the wrongfulness of the prosecutor's misconduct or to the harm inflicted on the defendant. Thus, it could be more satisfying in terms of desert, and more effective in condemning misconduct-significant enough to convey a serious message, but not so excessive as to engender resentment.

It is easier to see how this might work in some contexts than in others. In speedy trial cases, for instance, when a defendant has suffered years of serious stress but has ultimately been fairly convicted, a relatively significant sentence reduction might be justified in corrective terms. Such a remedy. would also serve the expressive purpose of condemning the prosecutor's misconduct. But complications arise when the harm experienced by the defendant seems quite minor, while the prosecutorial wrongdoing seems to merit an expressive remedy with some teeth. If sentence reduction is to be justified as an expressive remedy in such cases, it will have to be solely in terms of its value in condemning the prosecutor's conduct.

In these cases, sentence reduction is more likely to succeed in expressing condemnation if it is perceived as proportional to the magnitude of the prosecutor's misconduct. That is, the message's audience is likelier to tolerate a windfall that is unjustified in corrective terms-and thus to accept the message as morally legitimate - if the remedy satisfies the principle of desert in the retributive sense. The remedy must therefore be tailored to the wrong.

But what would it mean in practice to tailor a sentence reduction to the magnitude of the wrong or, for that matter, to the magnitude of the harm caused? One potential objection is that of incommensurability. It is difficult to define and quantify the non-conviction-related harm done by prosecutorial misconduct, much less its degree of wrongfulness. Translating either criterion into a number of years of reduction may be even more difficult: how many years of reduction is a seven-year delay in trial "worth," for instance? What about a failed attempt to hide exculpatory evidence?

A related objection concerns commodification: ${ }^{184}$ sentence reduction might risk sending the message that prosecutors may violate defendants' rights so long as they are willing to pay a price. If so, the remedy's expressive message might be undermined. Pricing, scholars have argued in other contexts, may reduce the stigma that attaches to bad acts-it treats them not as wrongdoing but as costs

184. I use this word in its broader, metaphorical sense, rather than to refer literally to market trading. See Margaret Jane Radin, Market-Inalienability, 100 HARv. L. Rev. 1849, 1859 (1987) (discussing different meanings of the term). 
of doing business. ${ }^{185}$

These objections are serious, but I do not think either provides sufficient reason to reject sentence reduction as a remedy. First, it would be incongruous to reject sentence reduction for these reasons when our legal system embraces money damages as a remedy for non-monetary injuries. Compensatory damages set values on such injuries, while punitive damages seek to quantify the "reprehensibility" of conduct. ${ }^{186}$ Both kinds of damages face commensurability problems ${ }^{187}$ and "price" violations in expressly monetary terms, just as goods are valued in market exchanges. ${ }^{188}$ In fact, sentence reduction may be less susceptible to commodification and commensurability objections than damages are. The remedy and its costs to the prosecution (or the "people") cut directly against the benefits the prosecution (acting for the "people") sought to gain through the misconduct. That is, the prosecution sought to take away the defendant's liberty for a certain amount of time; the sentence reduction restores some of that liberty. ${ }^{189}$ Unless government actors violate constitutional rights for the purpose of adding money to the treasury, damages do not offer this same correspondence between the wrong and the penalty. ${ }^{190}$

Damages, of course, are a time-honored way of redressing apparently unquantifiable harms; they are deeply embedded in our legal culture, which helps to lend them the moral legitimacy they need to serve as effective expressive remedies despite incommensurability concerns. Moreover, it is not necessarily incoherent to ask what an injury is "worth" in dollars-you can ask yourself what you would have to be paid to agree to suffer it. Likewise, we can sensibly talk about money damages as means of condemning wrongs. Plaintiffs' lawyers routinely ask juries to use punitive damages to "send a message" to the defendant, ${ }^{191}$ and fines may also be imposed as criminal punishment. It is the surrounding culture that gives those remedies their meaning-if we treat them

185. See, e.g., Uri Gneezy \& Aldo Rustichini, A Fine is a Price, 29 J. Legal Stud. 1, 13-14 (2000) (finding that when day care centers instituted fines for late pickup of children, late pickups increased, perhaps due to reduced stigma); Jonathan Remy Nash, Framing Effects and Regulatory Choice, 82 Notre Dame L. Rev. 313, 325-26 (2006) (discussing similar criticism of tradable pollution permits). But see Lior Jacob Strahilevitz, How Changes in Property Regimes Infuence Social Norms: Commodifying California's Carpool Lanes, 75 IND. L.J. 1231, 1262-64 (2000) (finding that pricing access to carpool lanes strengthened the pro-carpooling social norm).

186. E.g., State Farm Mut. Auto. Ins. Co. v. Campbell, 538 U.S. 408, 419 (2003).

187. See, e.g., Richard Abel, General Damages Are Incoherent, Incalculable, Incommensurable, and Inegalitarian (But Otherwise a Great Idea), 55 DEPAUL L. REv. 253, 270-82 (2006) (discussing tort damages); Levinson, supra note 61, at 410 (discussing constitutional damages); Radin, supra note 168, at $69-75$ (discussing tort damages).

188. See Richard Abel, Civil Rights and Wrongs, 38 Loy. L.A. L. Rev. 1421, 1430 (2005); Friedman, supra note 163 , at 288 .

189. Cf. Levinson, supra note 61, at 417 (arguing that the exclusionary rule "imposes on police [costs] ... . in the same currency as the benefits the police capture").

190. See id.

191. See White, supra note 161 , at 1279. 
as condemnatory acts, they are not merely "prices." 192

Analogous observations, however, apply to sentence reduction. Using years of liberty to "quantify" harm or moral wrongfulness is just as familiar to our legal culture as are money damages: liberty is the currency of the criminal law. Courts (and legislatures making sentencing laws) routinely quantify how "bad" conduct is in terms of the liberty of the person who commits it. The incommensurability problem is no more serious when the liberty in question is that of the victim of the wrong. It is perfectly coherent, for instance, to ask yourself how many months or years of your liberty you would give up to avoid a particular rights violation. Such an inquiry may put a "price" on your rights, but no more than criminal punishment itself puts a price on crime victims' rights. Few contend that we should stop punishing crimes-or punish them all with the death penalty-for this reason.

By issuing a sentence reduction, a court would thus measure its response to prosecutorial misconduct in the same currency used to punish the defendant's underlying crime: years of the defendant's liberty. This, in and of itself, might amount to an important expressive signal-it treats prosecutorial misconduct as fundamentally comparable to crime itself and worthy of moral condemnation in the same sense that crime is. Sentence reduction would attach quantitative values to wrongfulness and harm but in terms that we usually associate with condemnation, not with market transactions. ${ }^{193}$

Finally, there is also nothing new about the criminal justice system metaphorically "pricing" defendants' rights. Indeed, nearly all such rights are routinely "priced" by the plea-bargaining system, which allows defendants to trade them for reduced charges or sentences. ${ }^{194}$ Law and economics scholars have not had to stretch to describe this process in market terms. ${ }^{195}$ Current remedial schemes also can be described as pricing. Some are premised expressly on deterrencethat is, on the need to make violators pay. And for rights subject to harmless error review, the current price of violation is simply zero, except in the rare event that the court finds prejudice. By comparison, sentence reduction can hardly be said to devalue rights. ${ }^{196}$

192. See Saul Levmore, Norms as Supplements, 86 VA. L. Rev. 1989, 1990 (arguing that "norms help us to know whether to regard legal rules and sanctions as mere prices"); Radin, supra note 168, at 56,85 (arguing that compensation need not be understood as commodification).

193. See also Allan Manson, Charter Violations in Mitigation of Sentence, 41 CrIM. ReP. (4th) 318, 323 (1995) (Can.) (arguing, in Canadian context, that sentencing is an effective opportunity to express the value of constitutional rights because it is the aspect of the criminal process that "is most readily and widely communicated to members of the community").

194. See Albert W. Alschuler, The Changing Plea Bargaining Debate, 69 CAL. L. Rev. 652, 670-80 (1981).

195. See, e.g., Easterbrook, supra note 77.

196. See Jedediah Purdy, The Promise (and Limits) of Neuroeconomics, 58 ALA. L. Rev. 1, 32 (2006) (suggesting that "in practice when things have no price, we tend to treat them not as priceless but as worthless").

Gneezy and Rustichini's day care study does suggest that leaving violations unpunished might be better than imposing fines in terms of social stigma. See supra note 185 . But that study involved a small 
I do not mean to trivialize the difficulty of translating "badness" of misconduct into sentence-reduction-years. This difficulty may introduce a new source of potentially arbitrary variation in sentencing because different judges may disagree as to how much of a reduction particular misconduct is "worth."197 This variation may affect the expressive effectiveness of the remedy by interfering with the perception of desert. Moreover, the variations may not be random. In sentencing systems in which judges have a wide range of discretion, racial disparities in sentences have resulted; that problem was an impetus for the adoption of modern determinate sentencing schemes. ${ }^{198}$ Sentence reduction would reintroduce a new source of judicial discretion that could risk similar disparities-judges could subconsciously give less value to the rights of minority defendants when calibrating the reduction.

These problems could be alleviated considerably if the magnitude of the sentence reduction were fixed by statute. Such an approach would reduce the remedy's advantage in terms of tailorability, but a legislatively specified reduction need not be completely one-size-fits-all. Rather, it could achieve some degree of nuance by specifying different reductions for different kinds of violations and prosecutorial mental states. Inevitably, though, there will be some degree of tradeoff between tailorability and avoidance of disparity-a tradeoff that is familiar to sentencing policy more generally. ${ }^{199}$

But even if a sentence reduction scheme permitted complete judicial discretion as to the magnitude of the reduction, it is hard to imagine it producing more arbitrary variations in treatment than those produced by current all-or-nothing remedies. Under those schemes, a few defendants enjoy windfalls while most get nothing at all-and there is no sharp break between the situations of the lucky and unlucky ones that justifies these dramatic disparities. That would be a problem even if all judges drew the line between "all" and "nothing" at exactly the same place, but given the inherent subjectivity of the task, it would be astonishing if they did.

In sum, sentence reduction would serve corrective and expressive purposes better than current "stronger" remedies do. That advantage is compounded

fine-about $\$ 2.72$, far less than other publicly assessed fines in Israel. See id. at 4-5. The upshot may simply be that trivial "prices" are worse than nothing-they imply that the norm is not serious.

197. Similar translation problems infect jury awards of punitive damages, see, e.g., Daniel Kahneman et al., Shared Outrage, Erratic Awards, in Punitive Damages: How Juries Decide 31, 34-36, 40-41 (Cass R. Sunstein et al. eds., 2002) (finding that mock juries are consistent in assessing wrongfulness, but wildly inconsistent in attaching dollar figures), and there is no reason to assume judges are immune from such difficulties, see W. Kip Viscusi, Do Judges Do Better?, in PuNITIVE DAMAGES, supra at 186, 206. Indeed, traditional discretionary sentencing resulted in wide disparities, e.g., Stephen Breyer, The Federal Sentencing Guidelines and the Key Compromises Upon Which They Rest, 17 Hofstra L. REv. 1, 4 (1988), suggesting difficulty translating crime wrongfulness into sentence-years.

198. See, e.g., William W. Wilkins, Jr. et al., The Sentencing Reform Act of 1984: A Bold Approach to the Unwarranted Sentencing Disparity Problem, 2 CRM. L.F. 355, 359-62 (1991) (citing studies of pre-Guidelines sentencing disparity).

199. See Breyer, supra note 197, at 4 (discussing guidelines' objectives). 
because courts will likely be more willing to grant sentence reduction, in part due to the very advantages discussed here: judges, like everyone else, can be expected to resist remedies that they see as undeserved. If sentence reduction is perceived as fairer, it will thus be not only more effective in achieving its message but also likelier to be granted in the first place.

\section{E. REMEDIAL SENTENCE REDUCTION AND THE GOALS OF SENTENCING}

But does using the sentencing process to condemn prosecutorial misconduct risk unduly interfering with the traditional purposes of sentencing: retribution, deterrence, incapacitation, and rehabilitation? ${ }^{200}$ Or might it interfere with the expressive purposes of sentencing, muddling the sentencing court's message condemning the defendant's crime ${ }^{201}$ Here, I argue that such interference would in the great majority of cases be minor, justifiable, and comparable to current sentencing practice, and that remedial sentence reduction might even affirmatively promote some of the goals of sentencing. ${ }^{202}$

First, the expressive objection concerning "mixed messages" seems overstated. As Oren Bick has argued in the Canadian context, it should be fairly easy for judges "to make it plain ... that the 'discount' does not stem from reduced culpability, and cannot be expected in the future, by the offender or by others." ${ }^{203}$ Court decisions routinely encompass more than one message, and there is no reason the messages need get mixed.

As to retribution, if a sentence reduction is justified in corrective terms, it could actually serve the goals of retributive justice. That is, if the defendant has unjustly suffered some nontrivial harm due to misconduct-such as expressive injury-then reducing his sentence to the extent necessary to compensate for that harm ensures that he is not punished in excess of what is retributively justified. This rationale has been adopted by some courts in Canada, which are compelled by statute to follow retributive principles. ${ }^{204}$ Similarly, U.S. courts routinely offset another kind of state-imposed harm when determining sentences-time spent in pretrial detention-even though that harm, like that caused by misconduct, is not technically "punishment."205 Such offsets comport with basic retributive intuitions-to ignore prior state-imposed harms would

200. See Kent Roach, Section 24(1) of the Charter: Strategy and Structure, 29 CRIM. L.Q. 222, 262-63 (1987) (making this argument against sentence reduction in the Canadian context).

201. Such concerns have been cited in at least two Canadian decisions. See R. v. Carpenter, [2002] 2002 BCCA 301, TII 26-27 (Can.); R. v. Glykis, [1995] 24 O.R.3d 803, TII 21, 26 (Can.).

202. In a related piece, I argue specifically that sentence reduction is consistent with objectives federal courts must consider under 18 U.S.C. § 3553(a)(2). See Starr, supra note 8, at 31-33.

203. Bick, supra note 81 , at $224-25$. Bick asserts that courts will only be able to draw this distinction in situations where sentence reduction truly "corrects". a hardship to the defendant, id., but it is hard to see why such clarification would be impossible even in cases in which sentence reductions exceed what is correctively justified in order to serve expressive or deterrent purposes.

204. See id. at 219-22.

205. See, e.g., 18 U.S.C. $§ 3585$ (b) (2006); see also Starr, supra note 8, at $35 \mathrm{n} .45$ (discussing cases suggesting that retributive justice allows sentence offsets for other kinds of state-imposed harms). 
lead to unjustly excessive penalties.

Moreover, it seems unlikely that the possibility of remedial sentence reduction would noticeably reduce deterrence of crime. It is hard to imagine a potential criminal seriously weighing what remedial scheme would be in effect if he gets caught; his case goes to trial; it results in prosecutorial misconduct; and that misconduct is later detected. There are simply too many contingencies to make this possibility relevant to his calculus. As noted above, empirical evidence on deterrence of crime shows that people tend to disregard lowprobability outcomes. ${ }^{206}$

The incapacitation objection is potentially more serious, but ought not to preclude remedial sentence reduction except in a small number of cases. When a very long prison sentence (such as life) is truly necessary to incapacitate a dangerous defendant, I agree with Bick that " $[\mathrm{i}] \mathrm{t}$ could fairly be asked: can we instead choose a remedy that does not put the public at risk?"207 A sentence reduction scheme could provide exceptions for such circumstances, or it could provide "reductions" defined by the conditions of confinement rather than by the number of years. But I also agree with Bick that, for most sentences, incapacitation concerns provide no serious basis for objection to marginal reductions. To be sure, marginal differences in sentence length presumably do have some incapacitation effect on average ${ }^{208}$-but in most cases, the marginal increase in risk could be outweighed by competing considerations. ${ }^{209}$ In any case, existing sentences are not scientifically calculated to correspond to the exact length of time necessary for incapacitation. ${ }^{210}$

Fifth, as far as rehabilitation is concerned, remedial sentence reduction in general ought not to raise any serious concerns. Rehabilitation advocates typically push for shorter, not longer, prison sentences because the prison system does not generally rehabilitate effectively and may actually contribute to criminal tendencies. ${ }^{211}$ Indeed, remedial sentence reductions might facilitate rehabilitation in some cases, if courts were to implement them by replacing prison sentences with rehabilitative alternatives. However, remedial sentence reduction would be inappropriate in cases in which a defendant's base sentence does not include prison time, fines, or other clearly punitive components but instead

206. See supra notes $78-79$ and accompanying text.

207. Bick, supra note 81 , at 225.

208. See, e.g., Ilyana Kuziemko, Going Off Parole: How the Elimination of Discretionary Prison Release Affects the Social Cost of Crime 29 (Nat'l Bureau of Econ. Research, Working Paper No. 13380, 2007), available at http://www.nber.org/papers/w13380.pdf.

209. See Bick, supra note 81 , at 225.

210. See Hannah T.S. Long, The "Inequability" of Incarceration, 31 CoLuM. J.L. \& Soc. ProBs. 321, 333 (1998) (" $[A] c t u a l$ sentencing patterns are frequently inconsistent with the requirements of incapacitation. In fact, sentence length for violent offenders is inversely related to the likelihood of recidivism.").

211. E.g., Michael Edmund O'Neill \& Linda Drazga Maxfield, Judicial Perspectives on the Federal Sentencing Guidelines and the Goals of Sentencing: Debunking the Myths, 56 ALA. L. REv. 85, 108 (2004). 
consists solely of a rehabilitation-oriented alternative like drug treatment. In addition to the possible costs in terms of recidivism, it would not serve the corrective or expressive purposes of sentence reduction to grant a "remedy" that actually interferes with an effort to help the defendant. In such cases, perhaps courts should instead be authorized to grant remedial orders designed to mitigate the collateral consequences of the criminal conviction, such as expunging the conviction from the defendant's record upon completion of rehabilitation requirements. Similar record-clearing is already standard in most pretrial drug diversion programs, but defendants who complete court-ordered rehabilitation after convictions usually remain saddled with collateral consequences. ${ }^{212}$

Sixth, in an important way, sentence reduction could promote the underlying objective of all of the forward-looking purposes of sentencing: the reduction of crime. By illustrating that the defendant's rights are being taken seriously, sentence reduction could help to legitimize the criminal justice system and promote compliance with the law. Research in psychology and sociology has demonstrated that procedural fairness is crucial to the perceived legitimacy of legal systems, and that this legitimacy in turn encourages compliance with legal norms. ${ }^{213}$ These studies find that perceived procedural fairness is more important than the perceived substantive fairness of outcomes as a determinant of legitimacy and compliance. Thus, even if parties believe that the wrong result was reached in their case, they tend to accept it and comply if they believe that they were nonetheless treated in a procedurally fair manner. ${ }^{214}$ Moreover, legitimacy may have a "profound effect on behavior," as Tracey Meares observes, an effect that according to some studies greatly exceeds the deterrent value of penalties for noncompliance. ${ }^{215}$

Some of this literature specifically suggests that perceived procedural fairness

212. See, e.g., Deji Olukotun, Note, Harm Reduction Statutes and Immigrants in California: Removal of the Shadow-Class, 19 GEo. IMMIGR. L.J. 429, 437 (2005) (explaining different immigration consequences of pre- and post-conviction diversion); David Louis Raybin, Expungement of Arrest Records: Erasing the Past, TENN. B.J., Mar. 2008, at 22, 23-25, (explaining that Tennessee courts do not have the power to expunge convictions once entered).

213. E.g., Tom R. Tyler, Why People Obey the LaW 82, 107-08 (1990); Susan D. Franck, Integrating Investment Treaty Conflict \& Dispute Systems Design, 92 MINN. L. REv. 161, 214-15 (2007); Larry Heuer et al., The Role of Societal Benefits and Fairness Concerns Among Decision Makers and Decision Recipients, 31 LAW \& HuM. BeHAv. 573, 574 (2007) (noting that these findings are so consistent across legal, organizational, and political settings that they are among "the most robust findings in the justice literature'" (quoting Joel Brockner et al., Cultural and Procedural Justice: The Influence of Power Distance on Reactions to Voice, 37 J. EXPERIMTL. Soc. Psychol. 300, 301 (2001))); David A. Hoffman \& Michael P. O'Shea, Can Law and Economics Be Both Practical and Principled?, 53 ALA. L. REv. 335, 380 (2002); Tom R. Tyler et al., Armed, and Dangerous (?): Motivating Rule Adherence Among Agents of Social Control, 41 LAw \& Soc'y Rev. 457, 479 (2007) (observing that "values shape rule adherence, while procedural justice shapes values").

214. Franck, supra note 213, at 214-15; Tom R. Tyler, Does the American Public Accept the Rule of Law?: The Findings of Psychological Research on Deference to Authority, 56 DEPAUL L. REv. 661, 664,673 (2007); see Hoffman \&.O'Shea, supra note 213, at 380.

215. Tracey L. Meares, Norms, Legitimacy and Law Enforcement, 79 OR. L. REv. 391, 400 (2000) (citing studies). 
can reduce criminal recidivism. One study found that repeat incidents of spousal assault declined substantially when alleged perpetrators believed the police treated them fairly. ${ }^{216}$ The effect of perceived procedural fairness was independent of, and more important than, the incident's outcome (that is, whether the perpetrator was arrested). ${ }^{217}$ Likewise, Tom Tyler has found that criminal defendants' perceptions of the justice system's legitimacy turn less on the outcome than on the process. ${ }^{218} \mathrm{He}$ has also found that people who believe the police have been procedurally fair are less likely to commit various minor offenses $^{219}$ and more willing to assist the police in controlling crime. ${ }^{220}$

So what, then, determines perceptions of procedural justice? Parties tend to consider proceedings fair when they believe they have been treated with respect and that their rights have been taken seriously. ${ }^{221}$ It may be tempting to dismiss the dignitary injuries discussed earlier in this Part as trivial by comparison to the other concerns of the criminal justice system. I believe such a dismissal would be a mistake, as I have made clear above. But even those who do not take these harms seriously in their own right ought to consider their secondary impact on those very criminal justice objectives. Criminological research illustrates that procedural justice

may be important in reducing the level of anger that any contact with legal authorities may produce ... [and] strengthening one's bond to conventionality, even when these bonds may initially be quite tenuous .... [S]anctions, when imposed in such a manner as to insult the dignity of persons, can ... increase rather than reduce future offending. ${ }^{222}$

Remedial mechanisms are critical to perceptions of procedural justice. When there has been a departure from procedural fairness, it is crucial that there be a way to remedy the situation effectively to show respect for the rights that have been violated. As one group of scholars concluded: "To be perceived as procedurally fair, authorities must supply some mechanism by which decisions thought to be unfair or incorrect can be made right." ${ }^{223}$ Consistency in treatment is another important determinant of perceived procedural justice. ${ }^{224}$

The present remedial scheme for prosecutorial misconduct, unfortunately,

216. Raymond Paternoster et al., Do Fair Procedures Matter? The Effect of Procedural Justice on Spouse Assault, 31 LAW \& Soc'y Rev. 163, 163 (1997).

217. Id. at 191-92.

218. TYLER, supra note 213, at 110.

219. $l d$. at 108.

220. Tom R. Tyler, Trust and Law Abidingness: A Proactive Model of Social Regulation, 81 B.U. L. REv. 361, 377-86 (2001).

221. Meares, supra note 215, at 404; Paternoster et al., supra note 216, at 168; Tyler et al., supra note 213 , at $471-72,478$.

222. Paternoster et al., supra note 216, at 169-70 (citations omitted) (reviewing literature).

223. Id. at 168 .

224. Id. at $167-68$. 
does nothing to "make right" most wrongs, and the few windfall remedies it does grant are distributed haphazardly to a lucky few. In contrast, sentence reduction is a meaningful remedy that could be applied more consistently and could send a positive message affirming the defendant's dignity. It could thus promote the crime-prevention purposes of sentencing by reducing resentment of the legal system.

Seventh, even if remedial sentence reduction does sometimes interfere with the traditional objectives of sentencing, there is nothing new about balancing those objectives against other values. Sentences are often reduced because of competing interests-for instance, the "substantial assistance" a defendant happens to be able to give the government in another case. ${ }^{225}$ Moreover, sentences are often reduced due to prison overcrowding-a reflection of the routine tradeoffs the criminal justice system makes between punishment objectives and other legitimate social interests. ${ }^{226}$

Many scholars have argued that actual sentencing practice does not, in any coherent way, serve the traditional objectives of sentencing at all. ${ }^{227}$ For one thing, there is little consensus as to which of these traditional objectives should predominate, and they are sometimes at odds-for instance, a sentence designed for rehabilitative purposes will often be less punitive in character, potentially conflicting with the goal of deterrence. Sentences are often either subject to wide variation and arbitrariness when left to judicial discretion or based on determinate sentencing rules that are themselves simply premised on the statistical averages of past sentencing practices, rather than on any nuanced moral theory. ${ }^{228}$ Because objectives like incapacitation and rehabilitation may require individual tailoring, determinate sentencing inherently hampers courts' ability to achieve those objectives fully-yet legislatures have determined that the goal of uniformity outweighs that drawback. In any case, if base sentences do not track the purported objectives of sentencing, it is hard to argue that remedial sentence reduction would interfere unacceptably with those objectives by virtue of departing from those base sentences.

Finally, when they are actually granted, existing windfall-remedies for procedural violations more dramatically compromise the traditional purposes of sentencing than sentence reduction would. Sentence reduction can at least be tailored to serve the objective of proportionality relative to the defendant's sentence. The higher the base sentence, the smaller an equal-size reduction will

225. See U.S. Sentencing Guidelines Manual § 5K1.1 (2008).

226. See Mich. Comp. Laws.' ANN. $\S 801.57$ (West 2008) (ordering reduction of all prisoners' sentences in response to overcrowding); Jack Leonard \& Doug Smith, Hilton Will Do More Time Than Most, Analysis Finds, L.A. TMmes, June 14, 2007, at A-1 (discussing California early release program).

227. E.g., Kate Sttth \& Jose A. Cabranes, Fear of Judging: Sentencing in the Federal Courts 53 (1998); Adam Lamparello, Social Psychology, Legitimacy, and the Ethical Foundations of Judgment: Importing the Procedural Justice Model to Federal Sentencing Jurisprudence, 38 CoLUM. HuM. RTs. L. Rev. 115, 118-19, 141-42 (2006); Paul H. Robinson, The Federal Sentencing Guidelines: Ten Years Later, 91 Nw. U. L. Rev. 1231, 1241 (1997).

228. Lamparello, supra note 227, at 118-19, 136, 142-43; Robinson, supra note 227, at 1241. 
be relative to that sentence-in contrast to reversal or dismissal remedies, which amount to bigger windfalls the more serious the underlying crime.

\section{Applications}

This Part explores in greater detail several potential applications of the sentence reduction remedy. Sections A and B consider misconduct that currently triggers automatic remedies without being subject to harmless error review: speedy trial violations and race discrimination in jury selection, respectively. Section C considers sentence reduction as an appellate remedy for prosecutorial misconduct that is presently subject to harmless error review. In each of these contexts, the current remedial schemes have been subjected to vigorous scholarly criticisms. Sentence reduction could address the major problems identified by detractors of each without encountering the pitfalls presented by other reform proposals.

\section{A. SPEEDY TRIAL VIOLATIONS}

The Supreme Court has addressed the possibility of sentence reduction as a criminal procedure remedy in a single context: the Sixth Amendment's Speedy Trial Clause. The traditional remedy for violations has been dismissal of charges with prejudice. In Barker $v$. Wingo, the Court noted that this remedy is sometimes "unsatisfactorily severe" because "a defendant who may be guilty of a serious crime will go free." 229 Nonetheless, it concluded without further explanation that dismissal is the "only possible remedy."230

One year later, in Strunk v. United States, the Court was presented with a challenge to this conclusion. ${ }^{231}$ In Strunk, the Seventh Circuit found a speedy trial violation, and notwithstanding Barker's holding just two months earlier, ordered a sentence reduction as a remedy. ${ }^{232}$ It reasoned that the "severity" of the dismissal remedy "has caused courts to be extremely hesitant in finding a failure to afford a speedy trial .... [W] e know of no reason why less drastic relief may not be granted in appropriate cases."233

The Supreme Court unanimously reversed. ${ }^{234}$ This was unsurprising, given the court of appeals' disregard of its clear holding in Barker. Perhaps for this reason the Court offered little reasoning for its decision, stating merely that "prolonged delay may subject the accused to an emotional stress .... [O]ther factors such as the prospect of rehabilitation may also be affected adversely [by this stress]. The remedy chosen by the Court of Appeals does not deal with

229. Barker v. Wingo, 407 U.S. 514, 522 (1972).

230. Id.

231. Strunk v. United States, 412 U.S. 434 (1973).

232. United States v. Strunk, 467 F.2d 969, 972 (7th Cir. 1972), rev'd, 412 U.S. 434 (1973).

233. Id.

234. Strunk v. United States, 412 U.S. at 440. 
these difficulties." 235 . The Court gave no reason for why the sentence reduction remedy was insufficient, and it is hard to think of one. Of course sentence reduction could not eliminate the emotional stress that the defendant had suffered. But neither could any appellate remedy-including dismissalbecause that stress was past. The defendant was seeking a remedy to compensate him for harm already done. Sentence reduction, like dismissal, could serve that compensatory purpose, and unlike dismissal, it could do so in a way that is tailored to the magnitude of the wrong.

As critics such as Anthony Amsterdam and Akhil Amar have pointed out, dismissal with prejudice is only necessary when delays have rendered a fair trial impossible, perhaps because evidence has become unavailable. ${ }^{236}$ But this is not always the case; indeed, there was no such claim of prejudice in Strunk itself. Meanwhile, the other interests protected by the Speedy Trial Clause, such as avoidance of emotional stress and reputational injury, can be protected in other ways. If speedy trial claims are raised in an interlocutory posture, the court can take measures to expedite the process, including ordering the prosecutor to stand ready for trial. It can also release the defendant from detention. As to harms already suffered, dismissal is not the only or the best compensatory remedy. In cases in which the fairness of the trial was not affected by the delay, it overcompensates, giving an unnecessary windfall to guilty defendants. ${ }^{237}$ Nor is dismissal necessary to deter or condemn prosecutorial foot-dragging. Indeed, as discussed in Parts III and IV, sentence reduction may be more effective in achieving both purposes.

A better approach is to allow courts the option of sentence reduction (in addition to the above-mentioned interlocutory remedies) in cases in which a fair trial is still possible, notwithstanding the delay. Because courts would be more willing to invoke it, sentence reduction would be a more effective deterrent. And the windfall problem would be solved or at least mitigated substanitially. Thus, the court of appeals in Strunk may have picked the right remedy as a policy matter, albeit one that flew in the face of Supreme Court precedent.

Despite Strunk, scholars criticizing the dismissal remedy have not focused on sentence reduction as an alternative. ${ }^{238}$ Most have instead emphasized interlocutory remedies, ${ }^{239}$ which are necessary but not sufficient-they are solely oriented toward cessation of ongoing violations. They thus cannot correct or condemn past violations, nor can they deter effectively, because the prosecutor will go unpunished for harm already caused.

235. Id. at 439 .

236. Amar, supra note 30 , at 649-58; Amsterdam, supra note 30 , at 535-36.

237. See Amar, supra note 30, at 646; Amsterdam, supra note 30, at 539 .

238. Amar does note that sentences should be offset "for time served [in pretrial detention] to avoid double punishment," Amar, supra note 30, at 652, but this is routine and not remedial; defendants are always credited for time served even absent any constitutional violation.

239. Id. at 649-58; Amsterdam, supra note 30, at 535; Erik G. Luna, The Models of Criminal Procedure, 2 Buff. CrRM. L. Rev. 389, 430 (1999). 
This problem is not solved by Amar's additional proposal that defendants be permitted to bring suits for money damages for injuries that have already occurred. ${ }^{240}$ Although damages may be the best way to compensate acquitted defendants, ${ }^{241}$ they provide little recourse for convicted defendants, who are unlikely to win civil suits and thus have little incentive even to bring them. ${ }^{242}$ Indeed, Amar acknowledges that his scheme would not really benefit convicted defendants, and to him this is one of its prime selling points-the Sixth Amendment, he argues, is meant to protect the innocent, not the guilty. ${ }^{243}$

Even if so, however, it would still be necessary to provide remedies to guilty defendants because those remedies' expressive and deterrent effects benefit the innocent. Amar's damages remedy fails on both counts. The vast majority of criminal cases end in convictions, and Amar's proposal provides no effective expressive remedy in those cases - so the vast majority of prosecutorial misconduct would stand uncondemned. Civil suits would likely fail as a deterrent for the same reason. A prosecutor, when deciding whether to expedite her case preparation to avoid a speedy trial violation, would know that the defendant would very likely be convicted and have virtually no chance at a damages remedy. She might rationally choose to roll the dice. Sentence reduction is a better alternative on deterrent and expressive grounds.

Although the Supreme Court is unlikely to overrule Strunk, sentence reduction could be adopted as a remedy in speedy trial cases that do not involve violations of the U.S. Constitution. Congress could adopt it for violations of the Speedy Trial Act; ${ }^{244}$ state courts could adopt it for violations of speedy trial clauses in their state constitutions, which are sometimes more expansive than their federal equivalent; ${ }^{245}$ and state legislatures could adopt it for violations of their speedy trial statutes, which almost always are more expansive than the Sixth Amendment's protections. ${ }^{246}$ These provisions currently prescribe varied remedies, although dismissal is common. ${ }^{247}$ Indeed, remedies for these legislative and state constitutional provisions are more important than the Sixth Amendment remedy today because in light of these provisions' more demanding and specific standards, many more claims are brought under them. ${ }^{248}$

240. See Amar, supra note 30, at 669-70, 675-76.

241. The Rwanda Tribunal often orders conditional remedies: sentence reduction upon conviction or damages upon acquittal. See, e.g., Barayagwiza v. Prosecutor, Case No. ICTR 97-19-AR72, Decision on Prosecutor's Request for Review or Reconsideration, II 75 (Mar. 31, 2000).

242. See supra notes 57-59 and accompanying text.

243. See Amar, supra note 30 , at 670 .

244. The Speedy Trial Act of 1974, 18 U.S.C. $\S \S 3161-3174$ (2006), provided specific time limits for each stage in a federal criminal prosecution.

245. See Andrew M. Siegel, When Prosecutors Control Criminal Court Dockets: Dispatches on History and Policy from a Land Time Forgot, 32 AM. J. CRIM. L. 325, 357 n.116 (2005).

246. HeRMAN, supra note 30 , at 207; Siegel, supra note 245 , at $357 \mathrm{n} .116$.

247. See 18 U.S.C. $\$ 3162$ (requiring dismissal but allowing discretion as to whether it is with prejudice); Herman, supra note 30, at 204 (discussing the effect of the Interstate Agreement on Detainers).

248. Herman, supra note 30 , at 204. 


\section{B. RACE DISCRIMINATION IN JURY AND JURY VENIRE SELECTION}

In Batson v. Kentucky, the Supreme Court held that the Constitution prohibits prosecutors from striking jurors from a jury venire on the basis of race. ${ }^{249}$ Such discrimination, the Court held, violated both the juror's and the defendant's equal protection rights, as well as the defendant's Sixth Amendment right to a venire composed of a fair cross-section of his peers. Although the juror's rights are violated, the defendant alone receives the remedy. In Batson and subsequent cases finding similar discrimination, the Supreme Court has always reversed the defendant's conviction without applying harmless error analysis. ${ }^{250}$ It has thus treated automatic reversal as the appropriate remedy at the appellate stage. ${ }^{251}$

Automatic reversal, however, confers a windfall on the defendant in cases in which the Batson error does not undermine the validity of the conviction. Indeed, this windfall may be seen as especially glaring in a subset of the Court's Batson cases-those that do not even involve claims that the defendant's rights were violated. Interestingly, the Court has granted reversal even in cases that focused on the juror's rights alone. Consider its 1990 decision in Powers $v$. Ohio. ${ }^{252}$ Powers did not raise a Sixth Amendment issue because it involved the selection of the jury itself, and the Court had earlier held that the "fair cross-section" requirement applied only to the jury venire. ${ }^{253}$ Likewise, the Court never decided whether the white defendant's equal protection rights were violated by the exclusion of black jurors. Instead, it focused on the Fourteenth Amendment right of the juror and granted reversal on the basis of a violation of that right. ${ }^{254}$ But using the automatic reversal remedy to vindicate the juror's equal protection rights confers a windfall on the defendant-the remedy does not match the violation because it is given to the wrong person. ${ }^{255}$ As discussed in Part IV, this windfall problem could potentially undermine the expressive and corrective value of the reversal remedy.

Many scholars have defended the automatic reversal remedy despite this windfall, arguing that it is necessary to protect jurors who "have no ability to detect and correct violations" themselves by "giving defendants an incentive" to bring violations to light. ${ }^{256}$ Although jurors themselves receive no remedy, the

249. Batson v. Kentucky, 476 U.S. 79, 89 (1986); see also J.E.B. v. Alabama ex rel. T.B., 511 U.S. 127, 140 (1994) (applying this rule to sex-based strikes).

250. See Eric L. Muller, Solving the Batson Paradox: Harmless Error, Jury Representation, and the Sixth Amendment, 106 YALE L.J. 93, 116-17 \& nn.148-49 (1996) (discussing cases).

251. See Rivera v. Illinois, 129 S. Ct. 1446, 1455 (2009) (describing Batson as an "automatic reversal" case).

252. Powers v. Ohio, 499 U.S. 400 (1991).

253. Holland v. Ilinois, 493 U.S. 474, 478-89 (1990).

254. Powers, 499 U.S. at 406, 409, 413-14 (1991); see also Peters v. Kiff, 407 U.S. 493, 505 (1972) (likewise granting reversal in a case with a white defendant and no Sixth Amendment claim); Barbara D. Underwood, Ending Race Discrimination in Jury Selection: Whose Right Is It, Anyway?, 92 Colum. L. REv. 725, 734-36 (1992).

255. Henning, supra note 47 , at $788-89$.

256. Andrew D. Leipold, Constitutionalizing Jury Selection in Criminal Cases: A Critical Evaluation, 86 Geo. L.J. 945, 995 (1998); accord Albert W. Alschuler, The Supreme Court and the Jury: Voir 
risk of reversal deters prosecutors from violating their rights. ${ }^{257}$ These are real advantages, if the reversal remedy were actually implemented effectively-but remedial deterrence presents a serious problem. The drastic remedy makes judges reluctant to reverse convictions and too willing to accept pretextual race-neutral explanations for peremptory strikes. ${ }^{258}$ If violations are virtually never found, prosecutors can feel free to discriminate with impunity, and jurors remain unprotected. ${ }^{259}$

Sentence reduction could help to solve this dilemma. Batson violations could be subject to harmless error review with reversal required only in cases in which the verdict is unsafe and sentence reduction applied in all other cases. Reversal is not the only possible remedy that could provide defendants with an incentive to vindicate the equal protection rights of jurors-sentence reduction would carry the same benefit. ${ }^{260}$ And while sentence reduction would still provide some windfall to the defendant, the windfall would be much smaller than that provided by reversal.

Defenders of the reversal remedy might raise an expressive objection, arguing that only reversal can send an unambiguous message condemning race discrimination. ${ }^{261}$ Under this view, sentence reduction would send the message that race discrimination is, to some degree, tolerable. This objection is unpersuasive. To say that reversal is not warranted by a constitutional violation is not to say that the violation is acceptable, but rather that reversal is not the remedy that best fits the violation in light of other important social values at stake. Moreover, as discussed in section IV.C, the most dramatic remedy is not always the most effective one from an expressive perspective. Resentment of excessive windfalls may cloud the remedial message, making a less drastic remedy a better option.

Dire, Peremptory Challenges, and the Review of Jury Verdicts, 56 U. CH. L. REv. 153, 193-94 (1989); see also Powers, 499 U.S. at 414 (holding that the defendant should have standing to. raise the jurors' rights claim because, among other reasons, he "will be a motivated, effective advocate for the excluded venirepersons' rights," whereas excluded jurors rarely bring claims on their own).

257. See Covey, supra note 154, at 316; Henning, supra note 47, at 717.

258. See supra note 28 and accompanying text; Leonard L. Cavise, The Batson Doctrine: The Supreme Court's Utter Failure to Meet the Challenge of Discrimination in Jury Selection, 1999 WIs. L. REv. 501, 527-32 (reviewing cases showing overreliance on supposed neutral explanations); Gershman, supra note 52, at 441 (arguing that "prosecutors are becoming increasingly adept at articulating race-neutral reasons that often appear to be pretextual, but are commonly accepted by the courts").

259. See Karlan, supra note 28, at 2022-23.

260. See Calabresi, supra note 1, at 115 ("One of the things I have noticed as a judge is that even when people have been sentenced to thirty or forty years in jail, they fight desperately to get two points down on the sentencing guidelines."); Posner, supra note 99, at 623 (noting that defendants will appeal even when "the expected benefits may be slight" because "the expected costs are zero"). Of course, raising arguments has costs for defense counsel's time.. See Darryl K. Brown, Criminal Procedure, Justice, Ethics, and Zeal, 96 Mich. L. Rev. 2146, $2148-49$ (1998); Stuntz, supra note 82, at 32, 36-37. Still, if defense counsel has a good chance of winning an argument on appeal, she would be plainly irresponsible not to raise it even if the result would only be sentence reduction and not reversal.

261. E.g., Covey, supra note 154, at 316 (arguing that Batson "symbolizes official intolerance of discrimination in jury selection"). 
Most importantly, sentence reduction could provide an appellate remedy that courts would be willing to enforce. It could thus serve the purposes of the automatic reversal remedy better than that remedy itself does, providing a greater deterrent of prosecutorial discrimination in jury selection. Reversal would remain required for non-harmless cases and could be maintained as an option for other especially egregious instances, which would preserve any advantages that it offers while allowing for some remedy to be granted when courts are unwilling to reverse.

Finally, although the present automatic-reversal requirement could reasonably be defended on the ground that Batson violations are "structural," I find this argument ultimately unpersuasive. Structural errors are those that so affect "the framework within which the trial proceeds" that they "defy harmless-error review." 262 Batson violations would fall into this category if it were deemed necessarily impossible to speculate reliably as to whether a different juror would have decided the case differently. But it is not obvious that such an assessment is impossible in all Batson cases. Recently, in Rivera v. Illinois, the Supreme Court held that erroneous denial of a peremptory challenge was not structural error ${ }^{263}$ Plainly, then, just because an error affects the jury's composition does not necessarily mean it is not amenable to harmless error review.

Indeed, the harmless error analysis for Batson errors could look a lot like it does in most other contexts where courts currently apply harmless error review. Courts would ask: "Is the prosecution's evidence of guilt strong enough that absent the error, no reasonable juror could have acquitted?"264 If it is, then the substitution of one juror for another would be harmless; if the effect of the substitution cannot confidently be assessed, then reversal would be necessary. If we accept this "overwhelming evidence" standard in other contexts-and whatever its merits, courts do use it routinely - there is no logical reason not to apply it in the Batson context. ${ }^{265}$

Batson violations are thus susceptible to harmless-error analysis, though those that are deemed harmless should not be denied a remedy. Rather, defendants should be entitled to a sentence reduction-which in the end is likely to be a better remedy for defendants (as well as jurors) than automatic reversal, because courts will be more willing to grant it.

262. Neder v. United States, 527 U.S. 1, 8 (1999).

263. Rivera v. Illinois, 129 S. Ct. 1446, 1455 (2009).

264. See, e.g., United States v. Lane, 474 U.S. 438,450 \& n.13 (1986) (holding that most errors may be deemed harmless on the basis of "overwhelming evidence").

265. Other kinds of constitutional errors are routinely deemed harmless even though doing so requires considerable counterfactual speculation. For instance, the Supreme Court has approved harmless error review in cases in which jury instructions have omitted or misstated one of the elements of the crime. See Neder, 527 U.S. at 9-11 (compiling cases). It is not evident that substitution of one or two jurors is more of a "structural" error than failure to have any jurors adjudicate one of the elements. 


\section{HARMLESS ERRORS}

For most kinds of prosecutorial misconduct, most defendants receive no appellate remedy at all because the violations, even if egregious, are deemed harmless. The use of sentence reduction in such cases would address several significant objections raised by critics of the harmless error doctrine.

First, by eliminating the remedy for the great majority of violations, the harmless error doctrine seriously undermines deterrence. As Judge Harry Edwards puts it,

[w] hen evidence is not excluded, indictments are not quashed, and convictions are not overturned, we eviscerate the deterrent effect of these and other similar measures .... After all, we can hardly expect prosecutors to respect the rights of criminal defendants whom they believe to be guilty when ... judges are unwilling to do so. ${ }^{266}$

Many scholars have agreed that the doctrine may encourage prosecutorial misconduct. ${ }^{267}$

A second criticism is that the doctrine ignores constitutional values other than "accuracy in the determination of guilt." ${ }^{168}$ As Charles Ogletree argues, constitutional criminal procedure is designed "to restrain the government's human rights abuses ... and sometimes to protect the human dignity of the accused." 269 But by only redressing errors that affect the outcome of a trial, the Court "virtually tosses aside all other competing structural and constitutional values." 270 Thus, the doctrine is problematic both from a corrective justice perspective-it leaves non-conviction-related harms unremedied-and from an expressive one: in Edwards' words, it "infect[s] the entire criminal process with an ambivalence toward our most fundamental liberties." ${ }^{271}$ If mere words were enough to counter the expressive harms inflicted by procedural violations, then a finding that an error has occurred but is harmless might be perfectly satisfactory to vindicate the "other constitutional values" to which Ogletree refers. But as discussed in Part IV, words alone often "ring hollow" when unaccompanied

266. Harry T. Edwards, To Err is Human, but Not Always Harmless: When Should Legal Error Be Tolerated?, 70 N.Y.U. L. REv. 1167, 1195 (1995).

267. E.g., Alschuler, supra note 17, at 659; Charles F. Campbell, Jr., An Economic View of Developments in the Harmless Error and Exclusionary Rules, 42 BAYLOR L. REv. 499, 511 (1990); Bennett L. Gershman, The Gate Is Open but the Door Is Locked-Habeas Corpus and Harmless Error, 51 Wash. \& LeE L. Rev. 115, 131-32 (1994); Steven H. Goldberg, Harmless Error: Constitutional Sneak Thief, 71 J. CRIM. L. \& CRIMINOLOGY 421, 437-38 (1980); Sam Kamin, Harmless Error and the Rights/Remedies Split, 88 VA. L. REv. 1, 59 (2002).

268. Charles J. Ogletree, Jr., Arizona v. Fulminante: The Harm of Applying Harmless Error to Coerced Confessions, 105 HaRv. L. Rev. 152, 162 (1991).

269. Id. at 170.

270. Id; see also Tom Stacy \& Kim Dayton, Rethinking Harmless Constitutional Error, 88 Colum. L. REv. 79, 86-91 (1988).

271. Edwards, supra note 266, at 1195. 
by a remedy. ${ }^{272}$

Finally, the harmless error doctrine may impede the development of legal doctrine. Judge Edwards criticizes "judicial use of the harmless-error rule to avoid reaching a difficult issue in a case," which "leaves unresolved the question of whether an error even occurred, thus offering no guidance to trial courts." ${ }^{273}$ Many scholars agree with this "law-freezing" concern. ${ }^{274}$ To be sure, avoidance of constitutional questions is not always undesirable-indeed, in some contexts the constitutional avoidance canon requires courts to resolve cases on other grounds where resolution of the constitutional question is not necessary. ${ }^{275}$ But this canon is typically invoked in the context of judicial review of legislation or non-litigation-related conduct. Its concern with judicial overreaching seems inapplicable to appellate guidance to lower courts on procedural questions involving the conduct of the lawyers before them. The Supreme Court has never cited constitutional avoidance to justify skipping to the harmless error question and, indeed, has held that harmless error review "is triggered only after the reviewing court discovers that an error has been committed."276 Surprisingly, however, many appellate courts have simply ignored this holding and continue to bypass the question of error. ${ }^{277}$

Unfortunately, the cure that some scholars propose for these problemsabolishing harmless error review entirely for constitutional errors and replacing it with automatic reversal ${ }^{278}$ - may be worse than the disease. As discussed in Part I, automatic reversal can discourage courts from finding violations in the first place. The result may be "manipulation or strained interpretation of substantive rules in order to justify affirmance." 279 Indeed, weighed against the "law-

272. Friedman, supra note 163 , at 289.

273. Edwards, supra note 266, at 1182.

274. John M.M. Greabe, Mirabile Dictum!: The Case for "Unnecessary" Constitutional Rulings in Civil Rights Damages Actions, 74 Notre Dame L. Rev. 403, 405 (1999); accord Jeffrey O, Cooper, Searching for Harmlessness: Method and Madness in the Supreme Court's Harmless Constitutional Error Doctrine, 50 KAN. U. L. Rev. 309, 310-11 (2002); Martha A. Field, Assessing the Harmlessness of Federal Constitutional Error-A Process in Need of a Rationale, 125 U. PA. L. REv. 15, 61 (1976); Goldberg, supra note 267, at 435-36; Rex R. Perschbacher \& Debra Lyn Bassett, The End of Law, 84 B.U. L. Rev. 1, 39-40 (2004).

275. E.g., Spector Motor Serv. v. McLaughlin, 323 U.S. 101, 105 (1944); see Thomas Healy, The Rise of Unnecessary Constitutional Rulings, 83 N.C. L. Rev. 847, 851-58, 891-95, 935-36 (2005) (suggesting that the avoidance principle should be applicable to harmless error cases).

276. Lockhart v. Fretwell, 506 U.S. 364, 369 n.2 (1993); see United States v. Vilches-Navarrete, 523 F.3d 1, 23 (1st Cir. 2008) (Lynch, Howard, JJ., opinion of the court in part, concurring in part) (noting that Lockhart means the avoidance canon does not apply to harmless error cases); In re Fashina, 486 F.3d 1300, 1303 (D.C. Cir. 2007) (same); Richard H. Fallon, Jr., The Linkage Between Justiciability and Remedies-and Their Connections to Substantive Rights, 92 V. L. REv. 633, 660 n.90 (2006).

277. Healy, supra note 275, at 893; see, e.g., United States v. Cusumano, 83 F.3d 1247, 1250-51 (10th Cir. 1996) (ignoring Lockhart despite a dissent relying on it).

278. See Goldberg, supra note 267 , at $441-42$; Ogletree, supra note 268, at 167; James Edward Wicht III, There is No Such Thing as a Harmless Constitutional Error: Returning to a Rule of Automatic Reversal, 12 BYU J. PuB. L. 73 (1997).

279. Allen, supra note 24, at $332 \mathrm{n} .99$; Stuart P. Green, The Challenge of Harmless Error, 59 LA. L. Rev. 1101, 1102-03 (1999). 
freezing" objection is the possibility that harmless error may actually permit courts to adopt broader rights interpretations by insulating them from excessively costly remedies. ${ }^{280}$ Thus, replacing harmless error review with automatic reversal might actually retard the progressive development of, rights. Likewise, if courts systematically avoid finding violations, prosecutors are unlikely to be deterred from misconduct, and none of the defendant's interests will be well served.

Nor is tinkering with the harmless error standard, as some scholars suggest, ${ }^{281}$ likely to solve these problems. Harmless error standards have proven easy for courts to manipulate to achieve desired results-even the purportedly demanding Chapman test, which requires the prosecutor to prove constitutional violations harmless beyond a reasonable doubt. ${ }^{282}$ And to the extent that a new standard precluded courts from finding an error harmless, they might simply respond by not finding a violation.

Finally, even if (under any of the reform or elimination proposals) courts did end up reversing frequently, the resulting proliferation of retrials would significantly undermine judicial efficiency, which is the reason the harmless error doctrine was created. ${ }^{283}$ This cost would likely be disproportionate to the harm suffered by the defendant in many of the cases in which procedural violations do not affect the verdict.

A better alternative is to maintain harmless error review with regard to the question of whether the conviction should be reversed, but to allow or require a lesser remedy of sentence reduction when courts recognize "harmless" prosecutorial misconduct—perhaps better referred to as "non-conviction-related" rather than "harmless," in light of the harm it does inflict. This approach could provide an effective deterrent to prosecutorial misconduct and a measure of compensation for defendants' non-conviction-related injuries. It serves an expressive purpose, recognizing that prosecutorial misconduct is not truly "harmless" even when it does not affect the outcome of the trial. And it avoids the "law-freezing" effect-courts presented with a request for sentence reduction could not skip the merits of a constitutional question on the basis of harmlessness-but it does not exert the countervailing pressure against rights expansion that would come with the costly remedy of automatic reversal.

280. Fallon \& Meltzer, supra note 147, at 1799-1800; accord Ted Sampsell-Jones, Reviving Saucier: Prospective Applications of Criminal Laws, 14 Geo. Mason L. Rev. 725, 766 (2007).

281. See, e.g., Roger J. Traynor, The RIDDle of HARMLEss ERror 17-51 (1970); Cooper, supra note 274 , at 312-13; Edwards, supra note 266, at 1171 ; Field, supra note 274 , at 16; Stacy \& Dayton, supra note 270 , at 91-92.

282. See, e.g., Kamin, supra note 267, at 67-71 (showing that pro-death penalty justices on the California Supreme Court were vastly more likely than anti-death-penalty justices to deem constitutional errors in capital cases harmless).

283. See Henning, supra note 47, at 820; supra Part I (discussing the costs of retrials). 


\section{Practicalities}

Although this Article does not seek to work out all the details of a possible sentence reduction scheme, I offer here some initial thoughts on adoption and workability. First, I consider possible legislative and judicial mechanisms for initial adoption, in light of various constitutional and statutory constraints. ${ }^{284} \mathrm{I}$ then respond to a few practical objections concerning implementation.

\section{A. LEGISLATIVE APPROACHES}

Sentence reduction could be prescribed as a remedy for prosecutorial misconduct by .a legislature (or sentencing commission). Where determinate sentencing schemes exist, remedial sentence reduction could be built into them, for example, as a basis for a downward departure. As discussed in section IV.D, the magnitude of the departure could be left indeterminate or else specified, perhaps with a range of permitted reductions. ${ }^{285}$ If there is an "advisory" sentencing scheme-like the U.S. Sentencing Guidelines after United States v. Booker ${ }^{286}$ remedial departure could either be required or recommended with whatever force the guidelines themselves hold. Nothing in Booker or its predecessor Blakely v. Washington ${ }^{287}$ limits legislatures' power to specify mandatory sentence reductions. Only increases in sentencing exposure must be based on facts found by juries. ${ }^{288}$

Legislatures or sentencing commissions are thus free to create a sentence reduction remedy, but it would be up to courts to determine whether the remedy is constitutionally sufficient. When sentence reduction exceeds current remedies (as it would for "harmless" errors that now receive no remedy), this determination would presumably be no obstacle. ${ }^{289}$ Likewise, there would be no difficulty if the sole source of the underlying right were itself statutory-for example, if it were grounded in the jurisdiction's rules of criminal procedure or evidence or in its speedy trial statute. For such rights, the legislature is free to specify the remedy.

284. For a more thorough discussion of these options at the federal level, see Starr, supra note 8.

285. See supra note 199 and accompanying text.

286. United States v. Booker, 543 U.S. 220 (2005).

287. Blakely v. Washington, 542 U.S. 296 (2004).

288. Id. at 301; see also id. at 333 (Breyer, J., dissenting).

289. For simplicity, I assume that federal remedial legislation would cover federal courts while state legislation would cover state courts. However, Congress could in principle reach state court cases under its authority to specify remedies for states' violations of the Fourteenth Amendment. Cf. Craig Bradley, The Failure of the Criminal Procedure Revolution: A Response, 47 J. LEG. ED. 129, 130 (1997) (arguing that "Congress has the power, under section 5 of the Fourteenth Amendment, to promulgate a federal code of criminal procedure" applicable to state courts). States could be expected to challenge such legislation; the Supreme Court has permitted prophylactic Section 5 remedies that exceed constitutional requirements, but only if they are "congruent and proportional" to underlying constitutional violations. See City of Boeme v. Flores, 521 U.S. 507, 518-20 (1997). Sentence reduction legislation would be most likely to satisfy this standard if it were triggered only by clearly unconstitutional misconduct, see $i d$. at 519 , and if the legislature made findings concerning a pattern of such misconduct in state courts, see Bd. of Trs. of Univ. of Ala. v. Garrett, 531 U.S. 369, 370-72 (2001). 
In cases in which the right is constitutional in nature and sentence reduction is less than the current remedy, however, defendants can be expected to litigate its constitutional sufficiency. In the case of federal Speedy Trial Clause violations, as discussed in section V.A, the Supreme Court has already ruled that the remedy is insufficient, which would likely make contrary federal legislation futile. But for corresponding state constitutional claims, the remedial question in many states may be open to litigation.

What about Batson claims? Consider a hypothetical statute that orders sentence reduction in cases of prosecutorial race discrimination in jury selection but requires reversal only when the prosecution fails to prove that the verdict was unaffected. That is, the statute would replace the present remedy of automatic reversal with automatic sentence reduction plus reversal subject to harmless error review. The Supreme Court could and should approve such a remedial scheme. In none of its cases involving Batson claims has the Court engaged in extensive remedial analysis to justify automatic reversal-certainly, it has never considered and rejected the alternative of sentence reduction. ${ }^{290}$ Moreover, the sentence reduction remedy better serves the goals of deterring prosecutors from discriminating and encouraging defendants to challenge violations in light of the remedial deterrence problem that plagues the current scheme.

Legislatures cannot, of course, safely assume that their efforts to change constitutional remedies will survive judicial scrutiny. There is a chance that such legislation would be struck down. As Bill Stuntz argued in 1997 about possible legislative alteration of remedies for breach of the Miranda warning requirement, "legislative overruling is extremely risky. Courts could conclude that the [new remedy] ... is not an adequate replacement. And under current retroactivity doctrines, that would place at risk every criminal conviction in the trial and appellate pipelines in which evidence obtained under the new regime had been used."291

Stuntz's warning was prescient. Although the Supreme Court had never previously ruled that the Constitution actually required exclusion of evidence taken absent Miranda warnings, it did so in 2000 in Dickerson v. United States, striking down an alternative admissibility rule that Congress had adopted. ${ }^{292}$ Its prickly admonition that "Miranda, being a constitutional decision of this Court, may not be in effect overruled by an Act of Congress" signaled hostility to

290. See Muller, supra note 250, at $93 \mathrm{nn} .148-49$ (1996) (stating that the Court, as of 1996, had never actually held that automatic reversal was required). In its recent decision in Rivera v. Illinois, which was not a Batson case, the Court did describe Batson as having "held that the unlawful exclusion of jurors based on race requires reversal." $129 \mathrm{~S}$. Ct. 1446, 1455 (2009).

291. Stuntz, supra note 82 , at 53 n. 178 .

292. Dickerson v. United States, 530 U.S. 428, 432 (2000). 
Congress's attempt to play on its turf. ${ }^{293}$ Dickerson was a product of the longstanding debate about the exclusionary rule, and it is possible that the Court would be more deferential in other contexts. Still, if legislators are risk-averse, they might prefer to avoid substituting their own constitutional remedies for the Court's stronger ones, lest the Court reject the change.

That said, legislatively altering an appellate remedy, like reversal for Batson violations, would be much less risky than altering a rule governing admission of evidence. ${ }^{294}$ A hypothetical Supreme Court case holding that sentence reduction is an inadequate appellate remedy would not require much relitigation of other cases. Cases still "in the trial or appellate pipelines" 295 would not (yet) have been wrongly decided, while cases whose appeals were already decided would likely be unaffected by the decision under the Court's retroactivity doctrine. ${ }^{296}$ Thus, the retroactivity concerns Stuntz raises would be far less applicable. Legislatures might reasonably choose to act even in the face of a substantial chance that the legislation would be struck down.

\section{B. JUDICIAL APPROACHES}

Alternatively, courts could bypass the legislature and order sentence reductions themselves. When existing remedial requirements are themselves uncodified judicial creations, courts' authority to modify them is straightforward. For instance, in its next Batson case, the Supreme Court could hold that sentence reduction is a constitutionally adequate alternative to reversal of conviction, provided that the discriminatory selection of jurors did not affect the outcome of the case. In the Sixth Amendment speedy trial context, because of Strunk, only the Court could alter the remedy of dismissal with prejudice. State courts have similar authority with respect to judicially created state-law remedies.

The situation is more complicated when it comes to the judicial adoption of sentence reduction as a new remedy for misconduct that, under current law, receives no remedy at all. The Supreme Court has the supervisory authority "to prescribe rules of evidence and procedure that are binding" in federal courts, ${ }^{297}$ and state high courts enjoy similar prescriptive authority with respect to state

293. Id.; see John T. Parry, Constitutional Interpretation, Coercive Interrogation, and Civil Rights Litigation After Chavez v. Martinez, 39 GA. L. Rev. 733, 794 (2005) (noting that the "exact scope of Congress's power to alter remedies ... remains doctrinally unclear").

294. When trial judges identify racially discriminatory strikes, they can simply refuse to allow them. That remedy would not change under my proposal, although sentence reduction could be added as an additional deterrent remedy.

295. Stuntz, supra note 82 , at 53 n. 178 .

296. See Teague v. Lane, 489 U.S. 288, 308-10 (1989) (holding that new constitutional holdings generally do not apply retroactively, via collateral attack, to cases in which convictions have become final).

297. Dickerson, 530 U.S. at 437. 
courts. ${ }^{298}$ But this authority must yield to conflicting legislative or constitutional requirements. ${ }^{299}$ Courts thus must determine whether remedial sentence reduction is statutorily permitted, or alternatively, whether such reductions could be justified as constitutional requirements that would trump conflicting statutes.

The most obvious legislative hurdles to judicial adoption of remedial sentence reduction are harmless error statutes. Under 28 U.S.C. $\S 2111$, federal courts must "disregard" harmless errors-language that appears to preclude any remedy. Likewise, all fifty states have harmless error provisions in their statutes or constitutions. ${ }^{300}$ For several reasons, however, these provisions do not necessarily prohibit judicial adoption of remedial sentence reduction, even in cases in which appeals courts determine that prosecutorial misconduct has not affected the verdict.

First, not all state harmless error rules include language that goes as far as the federal rule. Instead of requiring all courts to "disregard" harmless errors entirely, some state provisions simply prevent appeals courts from reversing convictions. ${ }^{301}$ These provisions allow room for alternative appellate remedies like sentence reduction and certainly allow for trial courts to take prosecutorial misconduct into account in sentencing. If so, state courts would be free to apply remedial sentence reduction to federal constitutional errors occurring in state court, as well as to errors of state law. ${ }^{302}$

Second, courts have carved out many exceptions to the harmless error rules. Some of the existing exceptions provide room for remedial sentence reduction. For instance, the district court in Dicus relied on the Eighth Circuit's holding that harmless error review does not apply to breaches of plea agreements, which in turn relied on the Supreme Court's holding in Santobello, v. New York. ${ }^{303}$

298. See Thomas G. Saylor, Prophylaxis in Modern State Constitutionalism: New Judicial Federalism and the Acknowledged, Prophylactic Rule, 59 N.Y.U. ANN. SuRv. AM. L. 283, 309 (2003); Note, Courting Reversal: The Supervisory Role of State Supreme Courts, 87 YALE L.J. 1191, 1193 (1978).

299. E.g., Bank of Nova Scotia v. United States, 487 U.S. 250, 254 (1988) (holding that the Supreme Court has no supervisory power to displace the federal harmless error statute); Palermo v. United States, 360 U.S. 343, 345-48 (1959).

300. Chapman v. California, 386 U.S. 18, 22 (1967); Brandon L. Garrett, Innocence, Harmless Error, and Federal Wrongful Conviction Law, 2005 Wis. L. Rev. 35, 57 n.106.

301. See, e.g., Cal. Const. art. VI § 13; VA. Code. AnN. § 8.01-678 (2007); TenN. R. Crim. P. 52(a).

302. Although the question whether a federal constitutional error is harmless is itself a federal question, Chapman, 386 U.S. at 21, states apparently may adopt remedies for federal rights violations that federal courts would not grant in harmless error cases. In Delaware v. Van Arsdall, the Supreme Court suggested that a state court could adopt an automatic reversal rule as a "state prophylactic rule designed to insure protection for a federal constitutional right," so long as it made clear that the remedial rule was an "adequate and independent state ground" rather than being derived from the federal Constitution. 475 U.S. 673, 678 n.3 (1986); see also Connecticut v. Johnson, 460 U.S. 73, 91 (1983) (Powell, J., dissenting) ("A State, of course, may apply a more stringent state harmless error rule than Chapman would require."); $c f$. Danforth v. Minnesota, 128 S. Ct. 1029, 1038 (2008) (recognizing "the authority of the States to provide [post-conviction] remedies for a broader range of constitutional violations than are redressable on federal habeas").

303. United States v. Dicus, 579 F. Supp. 2d 1142, 1150 (N.D. Iowa 2008) (citing United States v. Mosley, 505 F.3d 804, 810 (8th Cir. 2007) (citing Santobello v. New York, 404 U.S. 257, 262-63 (1971))). 
More broadly, harmless error rules cannot preclude remedies that are constitutionally required ${ }^{304}$-including, arguably, remedies that courts conclude are necessary, as a prophylactic measure, to deter widespread constitutional violations. ${ }^{305}$ As discussed in Part III, courts could readily conclude that the use of remedial sentence reduction is necessary to deter prosecutorial misconduct adequately.

Third, the Supreme Court has specifically suggested that exceptions to the harmless error doctrine may be justified for prosecutorial misconduct that is "especially egregious" or constitutes part of a "pattern." This suggestion appeared in dictum in a footnote in Brecht v. Abrahamson ${ }^{306}$ and was recently cited approvingly in Fry v. Piller. ${ }^{307}$ Those cases concerned habeas relief; similar or even broader exceptions to the harmless error doctrine should logically apply at the district court level or on direct appeal, which do not involve the especially deferential habeas standard of review.

So far, courts have not taken up this suggestion in Brecht. As noted above, courts routinely deny relief for prosecutorial misconduct on the ground that it is harmless, and although many federal courts in habeas cases have acknowledged Brecht's so-called "footnote-nine exception," they have consistently deemed the facts before them insufficiently egregious to qualify for it. ${ }^{308}$ But this reluctance to follow the Court's suggestion may be explained by courts' general reluctance to reverse convictions, discussed at length above. If courts had the option to provide a less costly intermediate remedy like sentence reduction, they could and should be willing to recognize exceptions to the harmless error doctrine. After all, the fundamental purpose of harmless error review is to prevent unnecessary and costly new trials. ${ }^{309}$ Sentence reduction provides a way to protect the "integrity of the proceedings," as the Brecht footnote proposes, ${ }^{310}$ without contravening that purpose.

Another potential concern with judicial adoption of sentence reduction is whether it can be reconciled with existing sentencing legislation. This question has been the main source of controversy surrounding the permissibility of the remedy in Canada. ${ }^{311}$ If guidelines or mandatory minimums do not allow sufficient discretion to permit remedial sentence reduction, they may preclude

304. See Neder v. United States, 527 U.S. 1,7 (1999) (observing that the Court has continued to apply the automatic reversal rule to some constitutional errors notwithstanding the contrary text of Rule 52(a) of the Federal Rules of Criminal Procedure).

305. The Court has adopted such prophylactic remedial rules in other contexts-notably, the Fourth Amendment exclusionary rule. See, e.g., United States v. Leon, 468 U.S. 897, $906-07$ (1984).

306. Brecht v. Abrahamson, 507 U.S. 619, 638 n.9 (1993).

307. Fry v. Piller, 127 S. Ct. 2321, 2325 (2007).

308. E.g., Torres v. Mullin, 317 F.3d 1145, 1159 (10th Cir. 2003); Marshall v. Hendricks, 307 F.3d 36, 79 (3d Cir. 2002); Janecka v. Cockrell, 301 F.3d 316, 329 n.20 (5th Cir. 2002); see also United States v. Harbin, 250 F.3d 532, 544-45 (7th Cir. 2001) (referring to the footnote-nine exception in a direct appeal).

309. See United States v. Mechanik, 475 U.S. 66, 72 (1986).

310. Brecht, 507 U.S. at 638 n.9.

311. Compare R. v. Carpenter, [2002] 2002 BCCA 301, I 26 (Can.), with R. v. MacPherson, [1995] 166 N.B.R.2d 81, II 16 (Can.). See generally Bick, supra note 81 (discussing the controversy). 
courts from relying on their supervisory authority to grant such reductions because that authority depends on an absence of conflicting law. Sentence reductions would then have to be premised on courts' constitutional authority or else authorized by the legislature. But advisory guidelines, like the federal guidelines after Booker, should not present a problem. Although the weight accorded to such guidelines remains unsettled, the Supreme Court has made clear that courts have broad authority to depart from them. ${ }^{312}$

Thus, federal and many state courts have considerable room to adopt remedial sentence reduction, even absent action by legislatures or sentencing commissions. Still, to place the remedy on a firmer footing and clear up any doubts concerning whether the remedy is permitted by applicable statutes, legislative adoption is probably the ideal solution.

\section{IMPLEMENTATION CONCERNS: RESPONSES TO OBJECTIONS}

Regardless of which branch initially adopts a sentencing reduction scheme, its implementation raises some practical questions. In Part IV, I addressed concerns related to commensurability and disparity in the magnitude of reductions; here, I respond to a few additional objections.

One objection is the possibility that courts would just raise the base sentence to cancel out the reduction (especially if the reduction were mandatory). ${ }^{313}$ This is unlikely to happen often. First, in many jurisdictions, determinate sentencing schemes will limit courts' ability to manipulate the base sentence. ${ }^{314}$ Second, it is hard to see how an appeals court could engage in such manipulation because the trial court's sentence would presumably serve as the starting point for the reduction. ${ }^{315}$ Third, most courts are unlikely to want to raise the base sentence. As discussed in section II.B, most judges think sentences are generally too high. In addition, courts have sometimes expressed a desire for more effective remedies for prosecutorial misconduct. And the political and practical costs of sentence reduction are likely to be comparatively modest, reducing the incentive for judges to compensate. ${ }^{316}$ Fourth, any court that would manipulate the base sentence to avoid sentence reduction would surely engage in other kinds of

312. See Gall v. United States, 128 S. Ct. 586, 602 (2007) (holding that "the Guidelines are only one of the factors to consider when imposing sentence"). Moreover, although federal courts are required by 28 U.S.C. § 3553(a) to consider the objectives of retribution, deterrence, incapacitation, rehabilitation, and respect for the law, remedial sentence reduction is generally consistent with those objectives, for reasons discussed in section IV.E. See Starr, supra note 8, at 31-33 (developing these arguments).

313. See Amsterdam, supra note 30, at $535 \mathrm{n} .81$ (raising this objection in the speedy trial context); see also Caldwell \& Chase, supra note 10, at 71-72 (describing this as a "legitimate concern").

314. Caldwell \& Chase, supra note 10 , at 72.

315. Even if the appeals court remanded the case to the trial court for resentencing, the trial court would presumably be stuck with its own base sentence and could not increase it to compensate for the reduction; such an increase would be transparently retaliatory and thus forbidden. See Chaffin v. Stynchcombe, 412 U.S. 17, 24 (1973).

316. See Calabresi, supra note 1 , at 116 (arguing that severe sentencing laws mean that judges will not put a "thumb on the scale" to increase sentences). 
manipulation anyway (like narrowing the right) to avoid current windfall remedies. Finally, even if a court did engage in such manipulation, if it were well disguised, the sentence reduction might still achieve its deterrent and expressive purposes.

A variation on this concern is that prosecutors themselves will attempt to offset the impact of sentence reduction by exercising their discretion in ways that increase base sentences. This concern is more plausible because prosecutors have a significant incentive to keep the sentence high. Still, it is not so easy to see how this would work. Most of prosecutors' considerable power over sentences lies in their control over charging decisions and plea bargaining. ${ }^{317}$ But prosecutors tend already to exercise that control to maximize sentences, especially for defendants who choose to go to trial. ${ }^{318}$ Moreover, most of the kinds of misconduct I have discussed here generally take place at or close to trial, well after the charging and plea stages. So a prosecutor will usually not be able to respond, after committing misconduct and getting caught, by ramping up the charges. She could make a higher-than-usual sentence recommendation, but that would be fairly transparent and therefore likely less convincing to the court. She could start to charge more harshly in every case just in case she commits misconduct and gets caught. But any prosecutor so Machiavellian as to plan in all cases for the likelihood of her own misconduct is probably already charging the maximum. ${ }^{319}$ Finally, even if she did find a way to compensate for the sentence reduction in a particular case, she would not be able to avoid the reputational cost of being judicially chastised, which may be the most significant part of the sanction.

A third variation is that legislatures or sentencing commissions will respond by ramping up base sentences. Analogously, Bill Stuntz has argued that legislatures have historically responded to the expansion of constitutional criminal procedure by expanding the scope and penal severity of the substantive criminal law. ${ }^{320}$ These concerns might provide a reason to prefer reforms conducted through the legislature itself, if possible. ${ }^{321}$ That said, current stronger remedies are more politically explosive (albeit, rarer) and thus also risk triggering this kind of political response. Stuntz does not suggest that harsh sentencing legisla-

317. E.g., Jeffrey Standen, Plea Bargaining in the Shadow of the Guidelines, 81 CAL. L. REv. 1471, 1508-09 (1993).

318. See supra section III.C.

319. Relatedly, Bill Stuntz argues that expanded procedural protections induce prosecutors to change whom they charge, dropping cases that have likely procedural claims in favor of those that do not. Stuntz, supra note 82 , at 4,28 . However, that argument largely pertains to police procedure-charging practices are much less likely to be affected by improved remedies for prosecutorial misconduct, given the timing of that misconduct.

320. Id. at 7; William J. Stuntz, The Political Constitution of Criminal Justice, 119 HaRv. L. Rev. 780, 784 (2006); accord William T. Pizzi, Punishment and Procedure: A Different View of the American Criminal Justice System, 13 CoNST. COMMENT. 55, 66-67 (1996).

321. See Stuntz, supra note 320 , at $796,802-03$ (noting that legislatures sometimes expand procedural protections themselves even though they resent judicially created protections). 
tion is triggered by innovations in sentencing procedure specifically-rather, it responds to perceived "soft-on-crime" judging more generally. Moreover, intermediate remedial alternatives might be attractive to legislatures; when debating the Speedy Trial Act, for instance, many members of Congress expressed distaste for all-or-nothing remedial choices and a desire for effective remedies that did not amount to windfalls. ${ }^{322}$

Another possible objection is that judicial resources could be strained if defendants start raising claims that would otherwise surely be declared harmless. Canada's experience, so far, provides little basis for this concern, as "[i]n the vast majority of cases, the offender only asked for a sentence reduction once a preferred remedy, such as exclusion of evidence or a stay of proceedings, had been denied." ${ }^{323}$ Thus, reduction requests are adjudicated at the sentencing stage on the basis of submissions already made earlier in the proceedings. ${ }^{324}$ But if legislatures are concerned about an intolerably large increase in litigation (particularly at the appellate stage, where some appeals would likely be brought that would otherwise not have been pursued), they could consider limiting the remedy to cases involving serious prosecutorial misconduct. "Seriousness" could be defined in any of a number of ways. For instance, it could turn on whether the Constitution is violated, whether the misconduct was deliberate, or some combination of those factors. Such a limitation ought to discourage defense counsel from raising frivolous claims that they would not otherwise raise; any lawyer who currently declines to raise procedural errors that will likely be deemed harmless would presumably also decline to raise errors that would likely be deemed trivial. And if serious misconduct has occurred, then it would be a good thing if defense counsel had an incentive to bring it to courts' attention. Increased litigation under such circumstances is an acceptable cost. ${ }^{325}$

Finally, one potentially significant objection is that adding sentence reduction to courts' remedial options might encourage them to grant reductions when they would otherwise have granted reversal, mistrial, or dismissal, and that some defendants could be wrongfully convicted as a result. In principle, this risk should be avoided by confining sentence reduction to harmless error cases, in which courts have found that the reliability of the conviction is not in doubt. But in practice, of course, harmless error analysis can be wrong. It is possible that the availability of a compromise option might tempt some courts to apply the "harmless" label too liberally when they otherwise would not.

Although this concern is a serious one, I predict that such cases would be rare enough that the risk does not justify rejecting the sentence reduction proposal.

322. See Herman, supra note 30, at 205-06 (noting that "what remedy to provide had occasioned active debate in Congress because the choices-a severe remedy allowing alleged criminals to escape punishment or a remedy with few if any teeth-were not inviting").

323. Bick, supra note 81, at 230-31.

324. Id. at 230.

325. See United States v. Dicus, 579 F. Supp. 2d 1142, 1160 (N.D. Iowa 2008) (arguing that sentence reduction "provides an important incentive to defendants to raise issues of prosecutorial misconduct"). 
Because reversal, dismissal, and mistrial are already granted extremely infrequently, there is only a small pool of prosecutorial misconduct cases in which courts even could change their minds and decide to grant sentence reduction instead. There is good reason to believe that in most of the cases in that pool, the judges have significant doubts as to the defendant's guilt-if they do not have such doubts, courts already deem errors harmless. ${ }^{326}$ But in the cases in which judges are willing to grant new trials because they think the defendant is innocent, it seems unlikely that the availability of the sentence reduction option will often convince them to convict anyway.

Of course, even if only a few defendants are wrongfully convicted as a result of the availability of sentence reduction, that would be a substantial cost. But pragmatism requires considering the problem of wrongful convictions in the aggregate. The weakness of current remedies means that prosecutors are too likely to try to get away with misconduct-and often, they will get away with it, either because the misconduct is not detected at all or because the court does not provide an effective remedy. That means defendants are being wrongfully convicted because of prosecutorial misconduct now-indeed, studies of DNA exonerations show that prosecutorial misconduct is "one of the most common factors that causes or contributes to wrongful convictions."327 The best way to change that is to change prosecutorial behavior in the first place through effective deterrence or expressive remedies that build social norms against misconduct. ${ }^{328}$ Because a remedial scheme that includes sentence reduction will likely be more effective in terms of deterrence and expressive condemnation, it will probably reduce wrongful convictions on balance.

\section{CONCLUSION}

Current remedies for prosecutorial misconduct are strikingly ineffective, largely because courts view them as too costly to grant. Scholars have too often been unrealistic about this remedial deterrence problem, proposing stronger remedies for misconduct when the more realistic solution might be nominally "weaker" ones. Adding sentence reduction to current all-or-nothing remedial schemes would help to deter and condemn prosecutorial misconduct, while avoiding the social costs of retrial and providing a fair measure of relief to defendants whose rights have been violated.

This Article has sought to make the case for sentence reduction in terms of three distinct remedial purposes-deterrence, corrective justice, and expressive

326. See Anna-Rose Mathieson \& Samuel R. Gross, Review for Error, 2 Law, ProbabIITY \& Risk 259,266 (2003) (arguing that appellate courts "focus their attention primarily on the rare cases in which they think a defendant might be innocent, and paper over procedural errors in the rest").

327. Joy, supra note 17, at 403; see also Brandon Garrett, Innocence, Harmless Error, and Federal Wrongful Conviction Law, 2005 WIS. L. REv. 35, 111-12 (arguing that recent exonerations have revealed that many people are wrongfully convicted under our current harmless error framework).

328. See Joy, supra note 17, at 399-400 (arguing that better remedies and disincentives for prosecutorial misconduct are necessary to reduce wrongful convictions). 
condemnation-that in some situations might be in tension with one another. I have been deliberately agnostic as to the "proper" purpose of criminal procedure remedies for a couple of reasons. First, there may not always be one right answer-such remedies simultaneously serve multiple purposes, or different purposes in different contexts. Second, because I believe sentence reduction can effectively serve all three goals, there is no real need to choose-the case for sentence reduction, I hope, is over-determined.

With that said, of course there would be cases in which the various goals would support sentence reductions of different magnitudes. Most notably, in cases involving serious prosecutorial misconduct that, nonetheless, caused the defendant little identifiable harm, it might be necessary to grant a remedy that "overcorrects" in order to achieve effective deterrence or condemnation. Although I have offered a few thoughts on how to resolve such tensions, I have not proposed any firm rules for balancing competing interests or any formula for calculating the appropriate reduction. If my proposal were adopted, those details would be important subjects of further judicial, legislative, and scholarly debate.

Significantly, adding the option of sentence reduction need not mean giving up on the advantages that current "stronger" remedies may sometimes offer. Under my proposal, reversal would remain required when misconduct has compromised the reliability of the conviction, and dismissal with prejudice would be required when delays or other violations have rendered a fair trial impossible. Moreover, even in cases not involving that kind of prejudice, these strong remedies could remain available as an option for the exceptional cases in which courts are willing to invoke them. My proposal would eliminate the automatic remedies of reversal and dismissal for Batson and speedy trial cases but permit those remedies on a discretionary basis when necessary for deterrent, expressive, or corrective purposes. Sentence reduction would thus target misconduct that exists in the very large zone between proper conduct and extreme misconduct that currently triggers remedies.

Although this remedy is essentially unknown in the United States, adopting it would not require radical transformation to sentencing procedure. It is a simple and practical remedy that could readily be added to courts' remedial toolkit and offers the prospect of effective deterrence, meaningful condemnation, and a fair measure of compensation. There is by now a longstanding scholarly consensus that the current remedies for prosecutorial misconduct have failed. It is time to think creatively about solutions. 